Article

\title{
Airborne LiDAR Reveals a Vast Archaeological Landscape at the Nan Madol World Heritage Site
}

\author{
Douglas C. Comer ${ }^{1}$, Jacob A. Comer ${ }^{1, *}$, Ioana A. Dumitru ${ }^{1}$, William S. Ayres ${ }^{2}$, \\ Maureece J. Levin ${ }^{3}{ }^{\mathbb{D}}$, Katherine A. Seikel ${ }^{4}$, Devin A. White ${ }^{5}$ and Michael J. Harrower ${ }^{6}$ (D) \\ 1 Cultural Site Research and Management Foundation, 2113 Saint Paul Street, Baltimore, MD 21218, USA; \\ dcomer@culturalsite.com (D.C.C.); idumitr1@jhu.edu (I.A.D.) \\ 2 Department of Anthropology, University of Oregon, Eugene, OR 92403, USA; wsayres@uoregon.edu \\ 3 Archaeology Center, Stanford University, Stanford, CA 94305, USA; mjlevin@stanford.edu \\ 4 Department of Archaeology and Natural History, Australian National University, \\ Canberra, ACT 0200, Australia; k.seikel@anu.edu.au \\ 5 Autonomous Sensing \& Perception, Sandia National Laboratories, Albuquerque, NM 87123, USA; \\ dwhite@sandia.gov \\ 6 Department of Near Eastern Studies, Johns Hopkins University, Baltimore, MD 21218, USA; \\ mharrower@jhu.edu \\ * Correspondence: jcomer@culturalsite.com; Tel.: +1-410-916-7546
}

Received: 18 August 2019; Accepted: 11 September 2019; Published: 16 September 2019

\begin{abstract}
An airborne LiDAR survey of the Nan Madol World Heritage Site and adjacent Temwen Island revealed a complex, irrigated cultivation system, the first found in the Central and Eastern Caroline Islands. This informs the goals of the sustainable conservation project, funded by the U.S. Department of State Ambassadors Fund for Cultural Preservation, that inspired the survey, and expands understanding of Nan Madol and its place in the network of Pacific island interaction and trade. Fieldwork verified the presence, across Temwen, of low, wet, cultivable areas, many of which are connected by water channels or separated by earthen berms. The berms themselves may also have been cultivated. In complexity, labor investment, and organization, the system is comparable to Nan Madol itself, the largest archaeological site in Micronesia, with structures on about 100 artificial islets built of stone and coral on a reef flat. Constructed over a millennium, Nan Madol was the seat of the Saudeleur Dynasty, which persisted from about 1200 to 1600 CE. The cultivation system appears to have been able to provide ample food for consumption, feasting, and redistribution or trade. If the landscape alteration described here proves to date to the time of the Saudeleur Dynasty, it will offer many avenues of research into the economic basis of Nan Madol's regional dominance.
\end{abstract}

Keywords: LiDAR; Micronesia; Pohnpei; Nan Madol; hydrology; water management; remote sensing; archaeology; cultivation; site conservation

\section{Introduction}

An airborne LiDAR survey of the UNESCO World Heritage Site of Nan Madol and Temwen Island has revealed a vast archaeological landscape consisting of a network of cultivation features connected by a complex water management system. This landscape is adjacent to the core area of Nan Madol.

The LiDAR survey was completed to inform a sustainable conservation and management plan that is funded by the U.S. Department of State and conducted by Cultural Site Research and Management (CSRM) Foundation. Data products and models generated from the LiDAR data will guide the physical conservation and management of Nan Madol and enhance site interpretation. They also enrich understanding of the scope, organization, and influence of the Saudeleur Dynasty, which ruled from Nan Madol. The revealed features have the potential to inform the chronology and pattern of 
human settlement and occupation of Pacific islands. This discovery and further research are expected to open many avenues of inquiry.

While the Temwen cultivation system has not been physically dated, it has been examined on the ground. There are reasons to believe that it is coeval with Nan Madol. The labor investment necessary for forming and maintaining this vast and complex network parallels what would have been required for the construction of Nan Madol itself. While more research is needed, for example, to determine the cultivars being grown, the cultivation techniques used, and the periods of use, the discovery of this landscape of cultivation features suggests ways in which Nan Madol's economic strength may have contributed to a position of great influence on Pohnpei and in Micronesia, incentivizing populations of Micronesian atolls to maintain regular economic, social, and cultural links with Nan Madol via sophisticated sailing technologies and navigational techniques.

\subsection{Project and Site Overview}

In 2016, Nan Madol was inscribed onto the World Heritage List and simultaneously placed on the List of World Heritage in Danger. In 2018, the U.S. Department of State awarded a large Ambassadors Fund for Cultural Preservation grant to the CSRM Foundation to develop a Sustainable Conservation Plan that, when implemented, will provide the basis for removing or mitigating threats to the site by means of physical interventions and ongoing management and interpretation of Nan Madol.

Nan Madol is in Pohnpei State, one of the four state groupings of approximately 600 small islands that constitute the Federated States of Micronesia (FSM). Each of these groupings is arranged around one of the FSM's four volcanic, or high, islands. The island of Pohnpei, which is approximately seven degrees north of the equator, provides 336.7 square kilometers of the total 345.5 square kilometers of Pohnpei State. A reef and many smaller islands surround Pohnpei's main island. Among these smaller islands is Temwen Island (1.81 square kilometers). Pohnpei's topography is extremely rugged, and it is one of the wettest places on Earth, receiving four to five meters of rain each year [1].

The World Heritage Site of Nan Madol covers 0.767 square kilometers. The site's buffer zone, which is recognized and monitored by UNESCO, is 6.64 square kilometers (Figure 1). Temwen Island, a volcanic caldera, is within this buffer zone. It connects to the main island of Pohnpei via a short causeway, constructed in 1986.

Nan Madol is considered the largest archaeological site in Micronesia, and some have argued that it contains the earliest stone architecture in the Pacific [2]. The site consists of approximately 100 anthropogenic islets, built of basalt and coral, on the reef flat that extends from Temwen Island's southeastern shore into the ocean. Canals of seawater separate the islets, many of which feature stone and coral structures on top of them. In addition to their sizes, number, and location on the reef flat, the islets and structures are notable for the sizes of some of the basalt boulders used to build them and for the columnar, or prismatic, shape of thousands of the basalt pieces. This columnar quality is natural, and allowed for the stacking and laying of basalt pieces without having to shape them first.

Archaeological investigations indicate that the bulk of Nan Madol's islets and structures were constructed from approximately 1200 to 1600 CE [2-15]. Oral histories support these dates and associate Nan Madol, at least in its later stages, with the Saudeleur Dynasty. According to these accounts, the Saudeleurs, who ruled over the entirety of Pohnpei, were overthrown by an invasion of 333 warriors. This invasion was led by a warrior hero named Isokelekel, who came from an island to the east of Pohnpei $[16,17]$. Some have interpreted this as referring to Kosrae, another of the FSM's high islands.

A good deal of ethnographic, ethnohistorical, and archaeological research has focused on Pohnpei [3,6,7,17-24]. In 1967, Betty J. Meggers and Clifford Evans, of the Smithsonian Institution, cleared vegetation and conducted excavations at several islets that had been identified by Saul Riesenberg as having had specific or noteworthy functions. Some islets, for example, served as residences or burial places for Saudeleur elites, while others hosted rituals that enhanced the Dynasty's socio-political cohesion. Meggers and Evans's work supported Riesenberg's ethnographic research [25]. 
Riesenberg considered the Saudeleur Dynasty "a highly developed socio-political system that permitted the planning of the structures, organization of manpower to build them and to raise and feed the mass of labor necessary for construction" ([24], p. 5). Subsequent research has corroborated this interpretation, with many other researchers noting the high level of social complexity implied by the construction of Nan Madol [2,4-8,10,14,15,22,23,26,27]. Riesenberg's comment about the necessity of feeding laborers anticipates the findings on Temwen Island reported here.

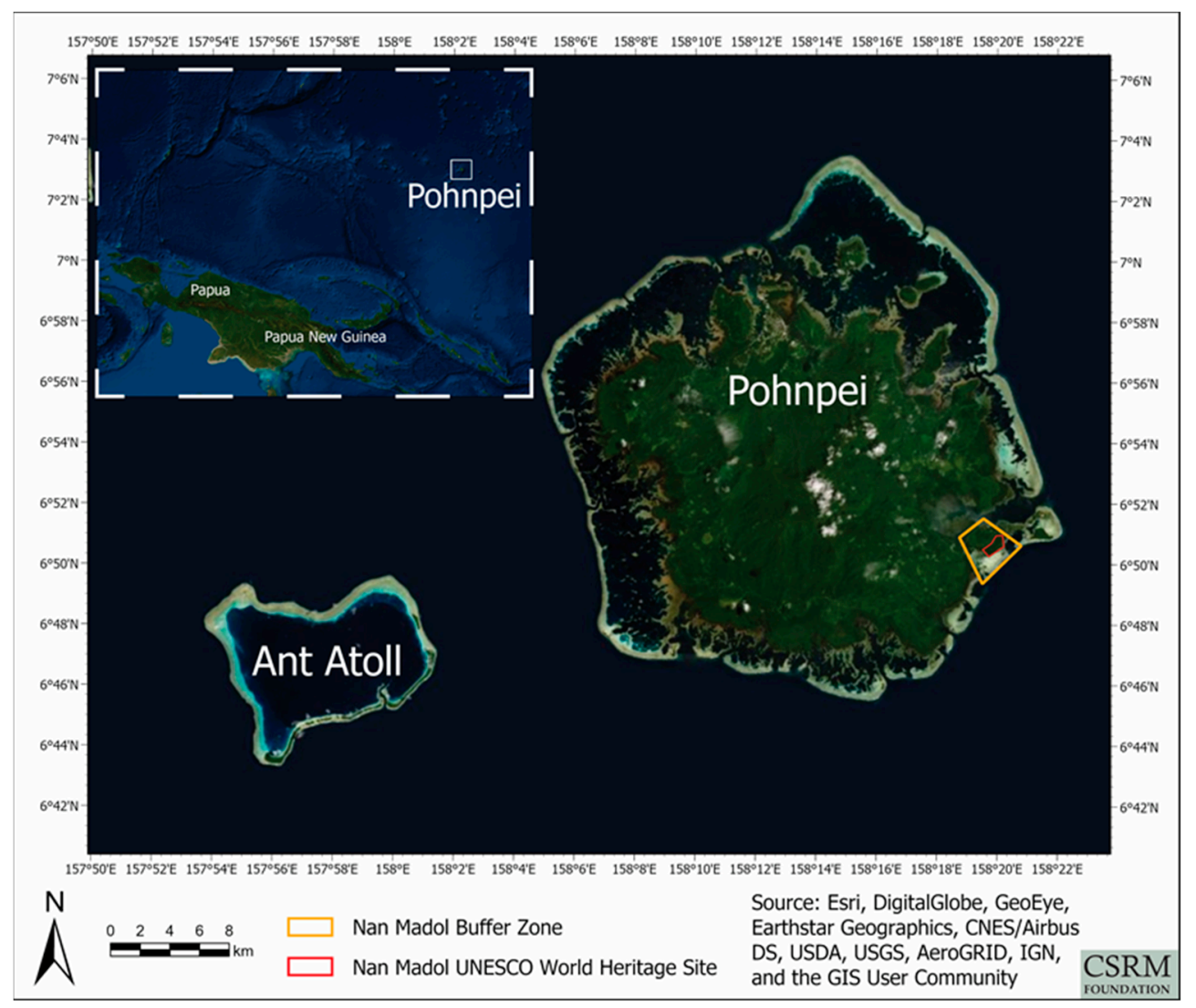

Figure 1. A regional map showing the location of the UNESCO World Heritage Site of Nan Madol and its buffer zone.

\subsection{Project Objectives}

The goal of the CSRM Foundation project is to develop a Sustainable Conservation Plan that will identify steps needed to remove Nan Madol from the List of World Heritage in Danger. This includes recommending physical interventions to mitigate threats to the site. Chief among these threats are (1) destructive vegetation; (2) siltation of the canals between islets, which has encouraged an environment that nurtures destructive vegetation and makes accessing the islets difficult; (3) erosion of islets and damage to structures caused by tidal action and storm surges (both of which become more destructive as the sea level rises); and (4) human activities that damage islets and structures. To be sustainable, conservation measures must include an interpretive plan and a management plan, which are necessary to site maintenance after initial treatments have been made.

LiDAR data was collected in order to assess the condition of Nan Madol's islets and structures; to assist in the identification of vegetation that threatens the structural integrity of the site; and to model Temwen Island's hydrology, in order to understand how it might be contributing to the siltation of the site's canals. Siltation and the proliferation of vegetation have progressed to such an extent that today, visitors can see little to suggest why Nan Madol was once called "The Venice of the Pacific." LiDAR's potential for distinguishing among vegetation, ground, and other features, and for yielding 
precise elevation measurements, figured prominently into the CSRM Foundation's decision to collect the data that led to this paper.

CSRM Foundation planned and oversaw the airborne LiDAR survey of Nan Madol and Temwen Island, which took place on 11 and 12 March 2019. It was undertaken by Aerial Surveying Inc., a Hawaii-based company specializing in LiDAR acquisitions. CSRM Foundation oversaw the preliminary data processing, much of which was done by Aerial Surveying Inc., and either oversaw or did all the data processing and analysis that followed.

As anticipated, it proved possible to classify and process the LiDAR data to develop several kinds of useful models. Some models reveal the landscape of Temwen Island and Nan Madol beneath the vegetation that blankets them, while others display the vegetative canopy itself. This was pertinent to the conservation objectives of the LiDAR survey, but it also resulted in the detection of the cultivation features on Temwen Island that are discussed below. In addition to providing the kinds of research opportunities mentioned above, these features are likely relevant to a myriad of archaeological and conservation-related matters, such as the original selection of the construction site for Nan Madol, the socio-economic system in which the islets emerged, and the alteration of Temwen hydrology that has contributed to the siltation of Nan Madol's canals.

\subsection{Terminology}

As the rest of this paper will reinforce, visual inspection of the LiDAR-derived products; fieldwork; and consultation of the literature on Pacific island archaeology, anthropology, and cultivation and agriculture indicate that the features revealed by the LiDAR survey described here were created by people to enhance Temwen Island's capacity for food production through the intensive cultivation of select species. But important details, such as which crops were grown in which areas and what methods were used to cultivate them, have not been ascertained with certainty. For that reason, the terms we use to describe the features revealed by LiDAR are empirically descriptive and nontechnical. For example, it is likely that the earthen berms described in Section 3 were used to cultivate certain crops, while the low, wet areas occurring between such berms were planted with others. Both berms and wet areas could be called fields, but that term has technical connotations we will avoid here.

The word agriculture is especially connotation laden, particularly in archaeology. Though its application to the features discussed here would be defensible, we opt for the arguably more general term cultivation.

\section{Materials and Methods}

In this section, we describe the methods of LiDAR data collection and analysis and the field methods used for validating the LiDAR data and ground-truthing the features visible in the LiDAR imagery.

\subsection{LiDAR Data Collection}

The LiDAR data were collected with a (full-waveform) ALIS560 sensor mounted to a Britten-Norman Islander, a small, two-engine, fixed-wing aircraft. The surveyed area (Figure 2) is 8.69 square kilometers and covers all of Temwen Island and Nan Madol. Mean flight altitude was $457.2 \mathrm{~m}$, mean ground speed was $46.3 \mathrm{~m}$ per second, the scan angle was $60^{\circ}\left( \pm 30^{\circ}\right)$, and the total swath width was $577 \mathrm{~m}$. There was total coverage between scan lines, making the overlap percentage $100 \%$. The data was output as WGS84 UTM Zone 57N, with elevations measured in meters above mean sea level (MSL), and using EGM2008 as the geoid model. The survey yielded 108.55 million recorded data points or returns. Each return consists of a $3 \mathrm{D}(\mathrm{x}, \mathrm{y}, \mathrm{z})$ spatial measurement, along with several other measurements, including intensity of return and red, green, and blue reflectances, that will be useful for future analyses. The mean number of returns per square meter was 11.93. 


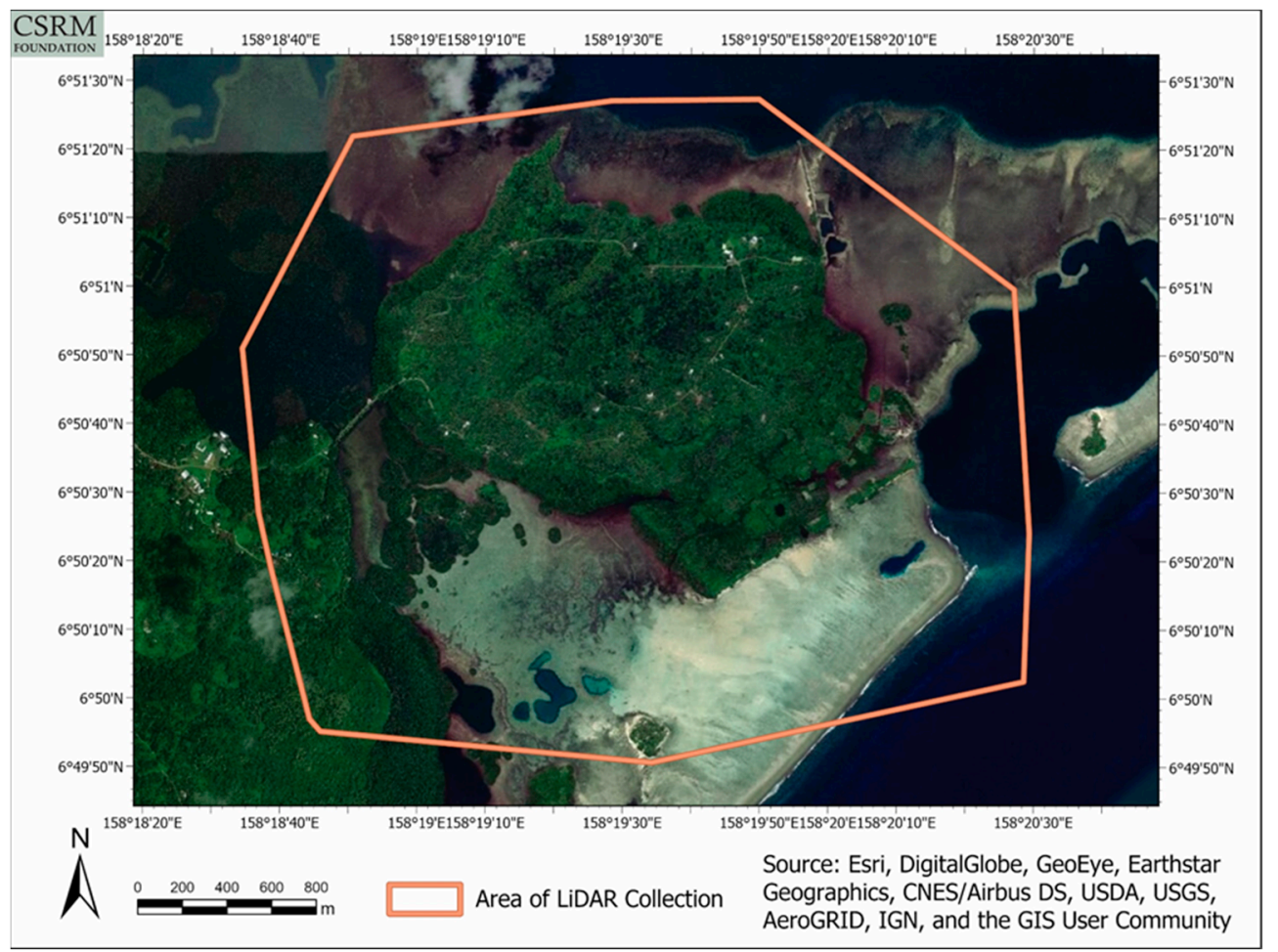

Figure 2. The area surveyed with LiDAR.

\subsection{LiDAR Data Analysis}

The combined point cloud for the entire region of interest was classified into ground and non-ground returns via the LP360 commercial software package, which is commonly used within the LiDAR community. The mean number of returns classified as having been reflected from the ground itself (called ground returns) was 2.7 per square meter. Once the point cloud was classified, it was used to create a Digital Terrain Model (DTM), a bare-earth representation of the ground surface, with 0.5 -meter post spacing. This DTM took the form of a georeferenced raster data product (sometimes referred to as a $2.5 \mathrm{D}$ product, as opposed to the original point cloud itself, which is 3D; see [28]) with $0.5 \times 0.5$-meter cells (Figure 3). LP360 was used to create the DTM as well.

Multiple products derived from the DTM were generated to highlight the archaeological features. We briefly describe seven of them here. The first derived product is a composite shaded relief image composed of 32,310 individual shaded relief products that were generated using a highly parallelized custom application written in C++. Azimuth angles from zero to 359 and elevation angles from 0 to 90 , which effectively represent a solar illumination dome over the region of interest, were used to ensure that subtle terrain features that might be visible only under specific geometric conditions could be highlighted. The shaded relief results of each azimuth and elevation angle combination were summed and then divided by the total number of products used, creating a normalized output. This derived product can be generated using standard commercial and open-source GIS software packages through relatively straightforward Python scripting, but the process would likely be very time consuming due to the single-threaded nature of those applications, unless some batch job orchestration system, taking advantage of multiple CPU cores, multiple computers, or both, was used. That is one reason why simpler versions of this product, like the multidirectional hillshade discussed below (Figure 4), are generally created instead. 


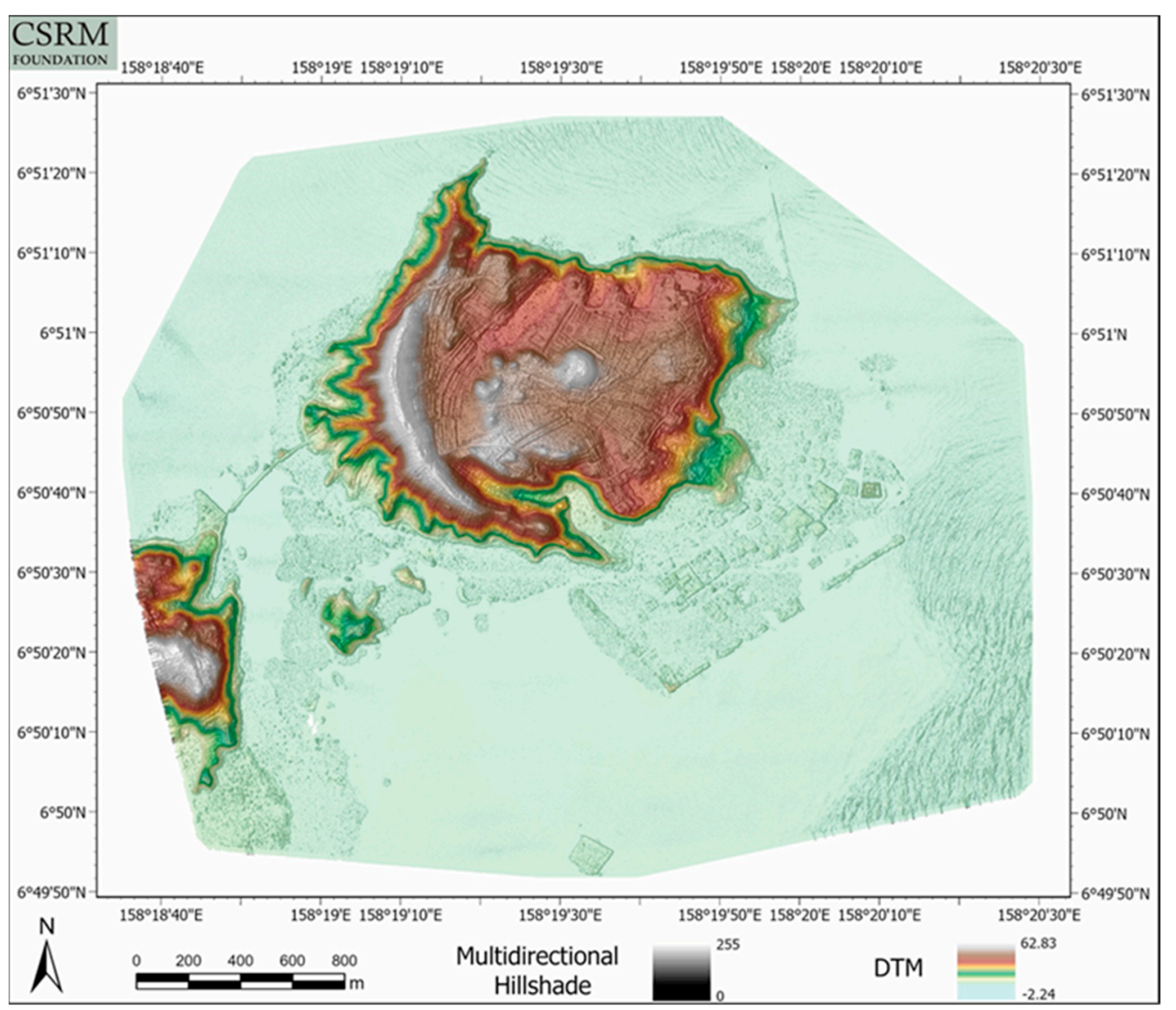

Figure 3. A colorized Digital Terrain Model (DTM) image overlaid on a multidirectional hillshade image.

The second derived product is a Sky-View Factor (SVF) image [29] that was generated using a highly parallelized custom application written in $\mathrm{C}++$. Instead of using a solar illumination dome (top-down), SVF evaluates how visible each cell in the supplied terrain model would be with respect to its neighbors (bottom-up) and assigns it a score between zero and one. While both composite shaded relief and SVF use the concept of a dome around a point of interest, SVF can sometimes be more effective at highlighting subtle landscape features. The custom application mentioned above is not required to create the product; the developers of SVF provide software on their website [30].

The third derived product is a multidirectional hillshade that was generated using the Hillshade function in ArcGIS Pro. A subset of the Surface functions, the multidirectional hillshade generates grayscale 3D terrain representations that combine light from six different directions, enhancing the visibility of terrain features. This tool proved particularly important for revealing the intricate patterns of flat areas, berms, and water channels on Temwen Island, many of which are subtle, low-relief features.

The fourth derived product is an estimated canopy height raster. It was generated by calculating the differences between the digital surface model (DSM, derived from the so-called first returns) and those provided by the digital terrain model (DTM, which is often called the bare earth model, derived from the ground, or last, returns). It models the estimated height of the vegetation canopy that covers Temwen Island and Nan Madol. As discussed in Section 4.1 Conservation Objectives, this product is particularly useful for identifying potentially harmful vegetation.

The fifth derived product is a raster of flow directions from each cell to the steepest downslope cell, generated with a traditional eight-direction (D8), pour-point flow modeling algorithm. This product can be represented as a 3D scene. It provides a visual model of the hydrology of Temwen Island and Nan Madol. 


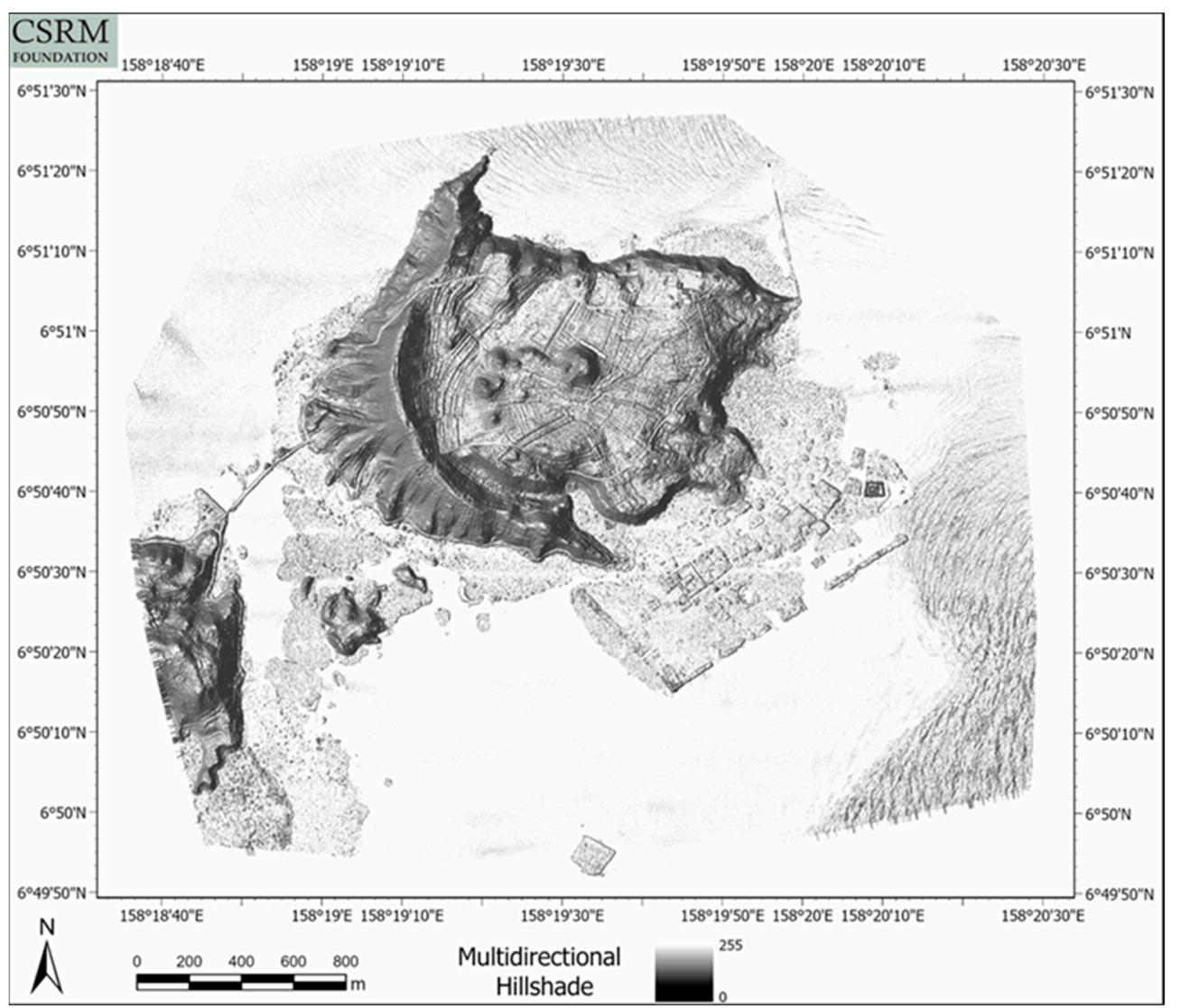

Figure 4. A grayscale, multidirectional hillshade image, derived from the LiDAR data set using ArcGIS Pro software. Both the cultivation features on Temwen Island and Nan Madol's islets are discernible.

The sixth derived product is a stream network created by analyzing the DTM with a Flow Accumulation tool, which reveals the number of upslope cells that flow into each cell. The product included in this paper has a threshold value of 100, presenting a model that only includes cells with more than 100 cells flowing into them. This threshold is a common choice as a default threshold for exploratory stream network analysis. The resulting model highlights real and potential streams and watercourses.

The seventh derived product, based on the DTM, simulates a sea level $1.4 \mathrm{~m}$ above MSL. It shows the impact that the higher sea level would have on low-lying terrain. All values below $1.4 \mathrm{~m} \mathrm{MSL}$ in the DTM were set to that value, after which a new SVF image was generated to highlight subtle terrain features. The DTM was then colorized, emphasizing variability between 1.4 and $10 \mathrm{~m}$ MSL, and overlaid on the SVF image.

\subsection{Identification of Areas of Interest for Field Verification}

Fieldwork to verify the presence and ostensible cultivation function of the features revealed by the LiDAR, and to validate and calibrate the LiDAR elevation measurements, was scheduled for 16-29 June 2019. In preparation, six priority areas were selected for inspection (Figure 5). These areas were selected chiefly on the basis of two criteria: Including particularly evident and representative examples of the features visible in the LiDAR data, and being relatively lightly covered by vegetation. The latter criterion was important to the performance of the Global Navigation Satellite System (GNSS) equipment used for verification and validation, which must have a relatively unobstructed view of the sky to achieve the most precise measurements possible (GNSS systems use global positioning system satellites as well as other constellations of positioning satellites). Temwen itself is almost entirely covered by thick vegetation, but we placed one of our areas of interest, Area 6, within Nan Madol, 
where some of the islets are relatively clear of vegetation. This allowed us to fully exploit the GNSS system's precision and gather highly accurate geospatial measurements (see Section 3.1 for details). For later analyses, many of which will be relevant to the Sustainable Conservation Plan, these data will be quantitatively compared with the LiDAR data, to verify and validate the elevations measured for Nan Madol's islets.

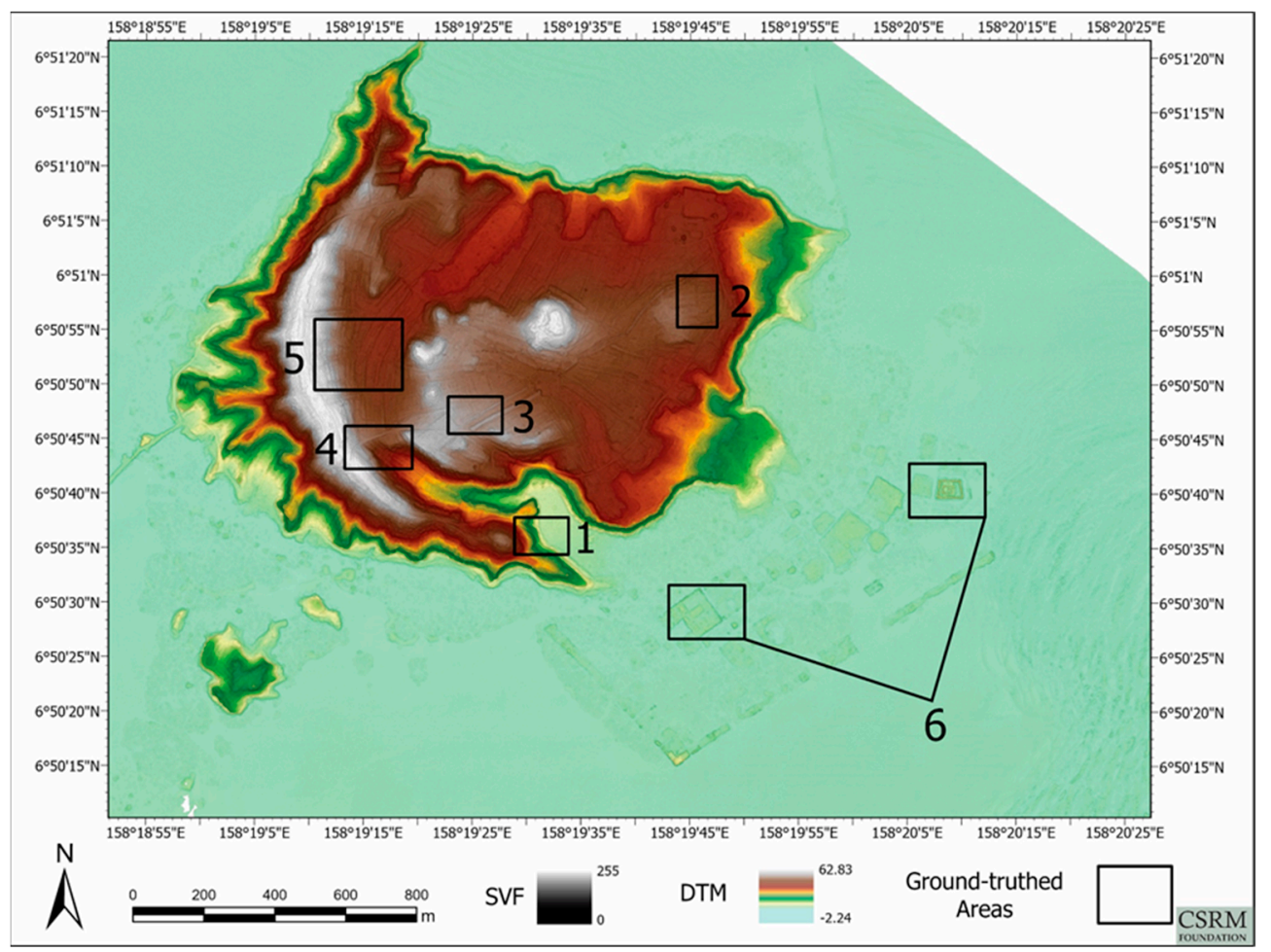

Figure 5. The six areas of interest chosen for field verification of the features revealed by LiDAR and for validation and calibration of the LiDAR data.

Another area of interest, Area 1, was chosen because it appeared, in the LiDAR data products, to play critical roles in the current hydrology on Temwen Island and downstream in Nan Madol. Areas 2-5 were chosen on the basis of the first criterion mentioned above.

\subsection{Field Verification}

Georeferenced LiDAR-derived images, such as the shaded relief product described in Section 2.2, were loaded on iPads and used to navigate to the six areas of interest through the ArcGIS Collector application. Preparing these maps for use in the application was done with ArcGIS Online. ArcGIS Collector also allowed the fieldwork team to add point, line, and polygon features to the maps loaded onto the iPads while in the field. Another application, the GPS Camera 55 Field Survey, automatically recorded the location, elevation, time acquired, and direction of each photo taken with the iPads, and it allowed the team to add notes to the photos.

Pohnpei State Historic Preservation Office (HPO) personnel and Temwen Island landowners were informally surveyed for information about archaeological feature locations. HPO personnel used machetes to clear vegetation from parts of the areas of interest. Without clearing vegetation, discerning and identifying the cultivation features under Temwen's profuse plant growth would have been extraordinarily difficult. HPO and Pohnpei State Department of Land personnel identified the owners of the parcels of land where the areas of interest were located. The HPO was instrumental in getting landowner permission to access and clear vegetation from the parcels. The GNSS system was used to collect data not only for validating and calibrating the LiDAR data (in future analyses), but also to confirm and record the locations of features visible in the LiDAR-derived products. Because 
the system records precise geospatial data in three dimensions, these data were used, and can be used further in the future, to verify and compare not only the shapes and locations of the Temwen features in horizontal, plan view, but also in terms of their elevations and profiles.

\section{Results}

Products derived from the LiDAR data set not only prove themselves useful for preparing the Nan Madol Sustainable Conservation Plan, but also revealed, to all appearances and in accordance with Pohnpei's larger archaeological context, a sophisticated and extensive landscape of cultivation features hidden under Temwen Island's vegetation. Ground verification supported this interpretation. Along with notes and georeferenced photos, GNSS measurements confirmed and recorded the shapes, layouts, and locations of the features.

\subsection{GNSS Accuracy}

Precise cartographic data was gathered using Trimble GNSS receivers supplied by the Spatial Observation Laboratory for Archaeological Research (SOLAR) at Johns Hopkins University. A Trimble R10 receiver was used as a base station and a Trimble R2 as a rover. Differential correction of the rover data was performed using Trimble GPS Pathfinder Office software. All points collected in Area 6, which proved to offer good access to the sky, had accuracy estimates of zero to five centimeters after post-processing. On Temwen Island, where vegetation is far denser, precision was often compromised (Table 1). However, elevations obtained in areas with less tree cover have accuracies comparable to those of the measurements obtained during the LiDAR survey.

Table 1. Estimated horizontal accuracies, after post-processing, of the Global Navigation Satellite System (GNSS) points collected on highly vegetated Temwen Island.

\begin{tabular}{cc}
\hline Percentage (\%) & Accuracy Range $(\mathbf{c m})$ \\
\hline 20.38 & $0-5$ \\
2.06 & $5-15$ \\
3.86 & $15-30$ \\
12.16 & $30-50$ \\
24.66 & $50-100$ \\
22.29 & $100-200$ \\
14.08 & $200-500$ \\
0.50 & $>500$ \\
\hline
\end{tabular}

\subsection{LiDAR Analyses and Models}

Quantitative analyses of the LiDAR data, which were mostly restricted to statistical characterizations of the distributions of elevation measurements, and visual analysis of the products derived from it yielded several conclusions. Visualizations of the LiDAR data products display the structural integrity of Nan Madol's islets and the structures on them. The islets' and structures' outlines are clear. Many islets have been visibly, profoundly affected by periodic inundations associated with normal and extreme tidal cycles and storm surges. Many structures, even on relatively intact islets, have evidently been damaged not only by inundation, but also by vegetation on the islets and in the canals between them. The siltation of the canals seems to be related to this process (Figure 6). This phenomenon has been noted previously by several observers on the ground [31,32] (but see also [33]). Certain products make visible the extent and density of mangrove growth in and near Nan Madol. 


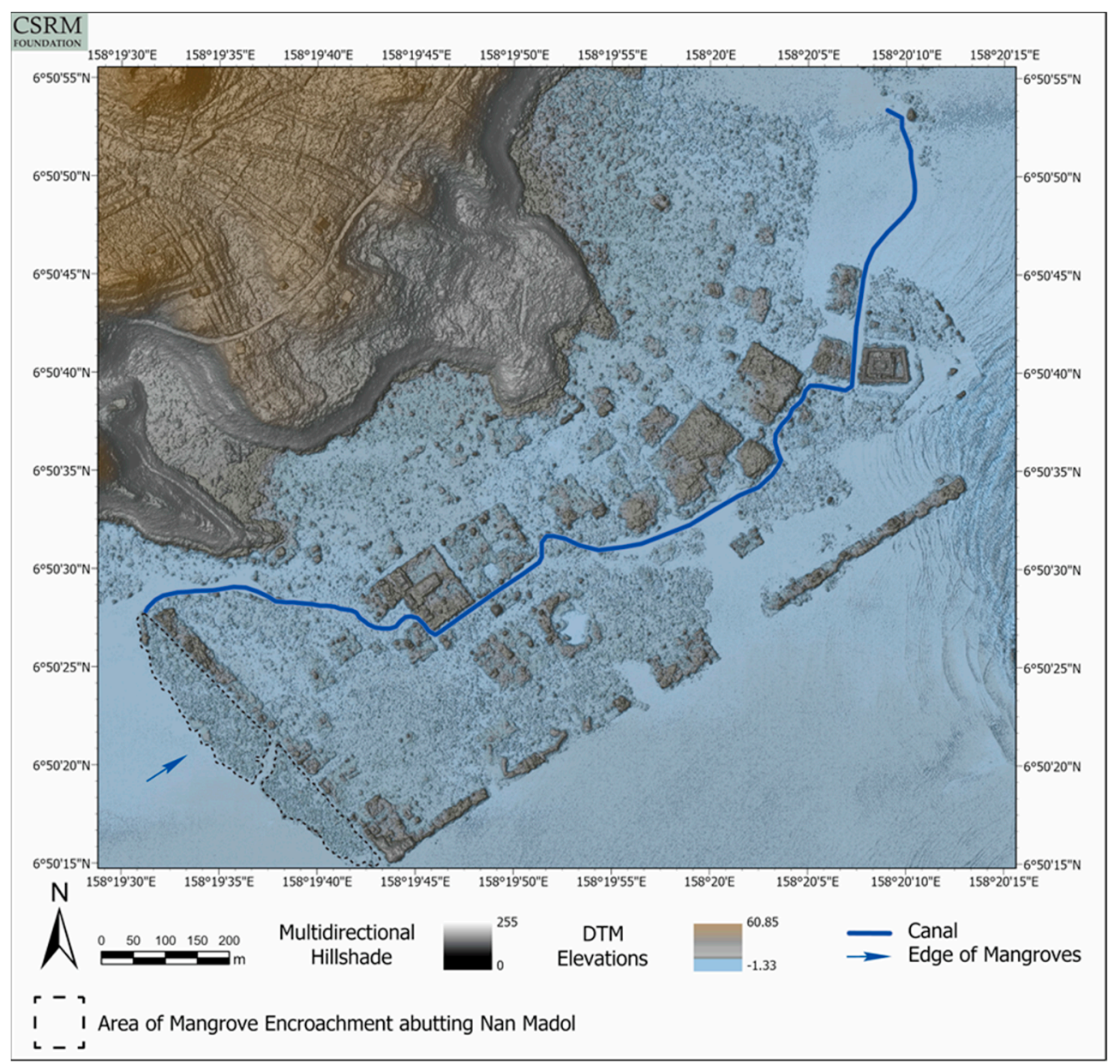

Figure 6. A multidirectional hillshade overlaying a colorized DTM. Some islets and structures have visibly better structural integrity than others do. This product also reveals the extent and density of mangrove growth (the polygon encompassing an area of mangrove encroachment along Nan Madol's southwestern edge is meant to be expository, not comprehensive). The blue line denotes one of Nan Madol's principal canal systems, which runs past several of the largest and best-preserved islets.

Some of the LiDAR-derived data products, and in particular the inundation-simulation product described in Section 2.2, make it possible to quantitatively and visually model phenomena that threaten Nan Madol, such as normal and extreme tides and storm surges (Figures 7 and 8). By continuing to work with these models and to use LiDAR elevations calibrated with the precise elevation measures collected with the GNSS system, these models can be made more accurate. With more accurate models, better assessments of conservation threats associated with wind and water can be made.

Data products that include canopy height calculations allow for the mapping and easy identification of high vegetation, which poses special threats to Nan Madol, such as falling branches and trees (Figure 9). These products allow us to identify potentially harmful species, and even especially threatening individual plants. 


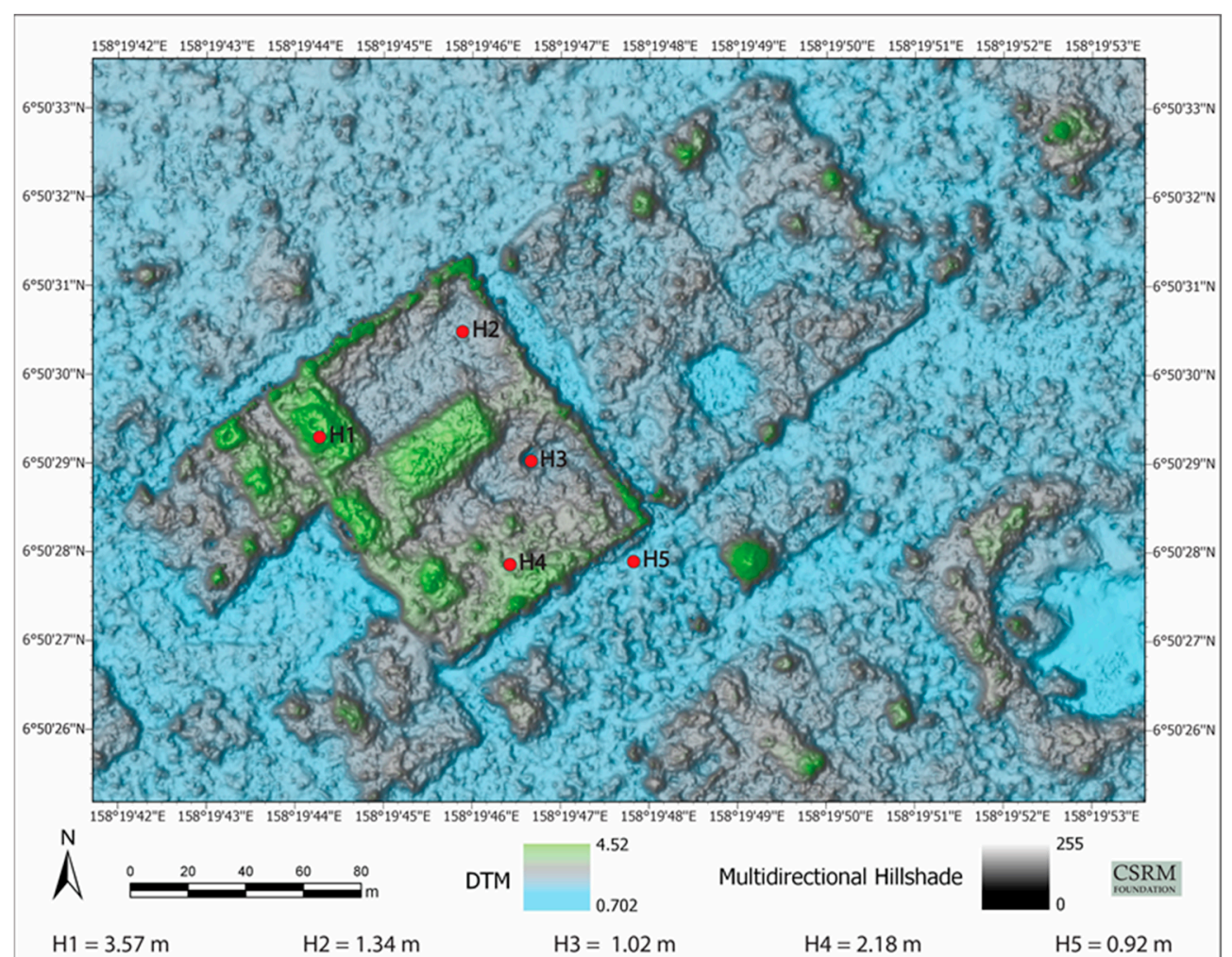

Figure 7. LiDAR-measured elevations on Pan Kediera (H1-H4) and in the main canal running past the islet (H5).

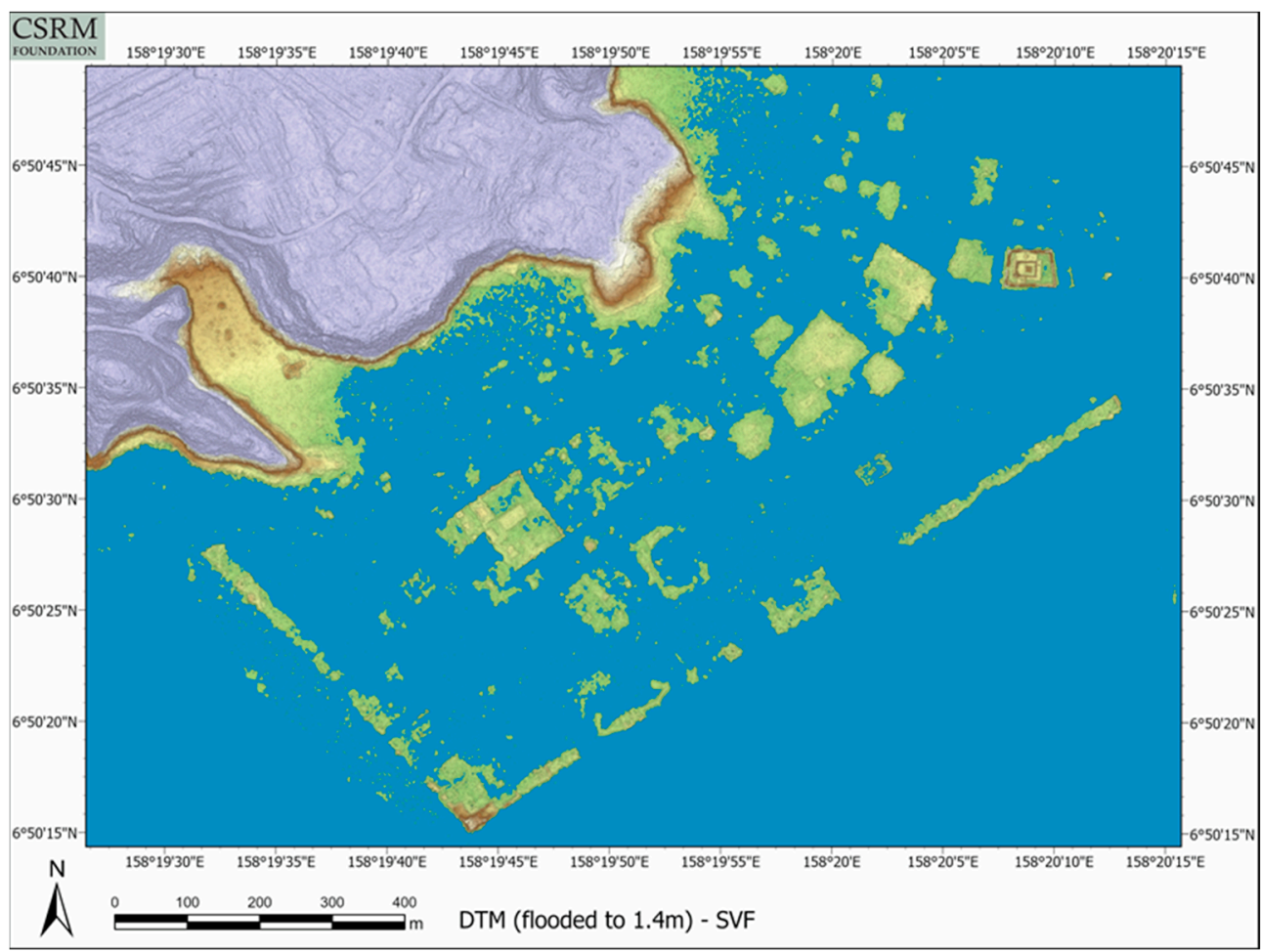

Figure 8. An inundation-simulation model: A DTM visually flooded to $1.4 \mathrm{~m}$ on SVF with 5.0 vertical exaggeration. 


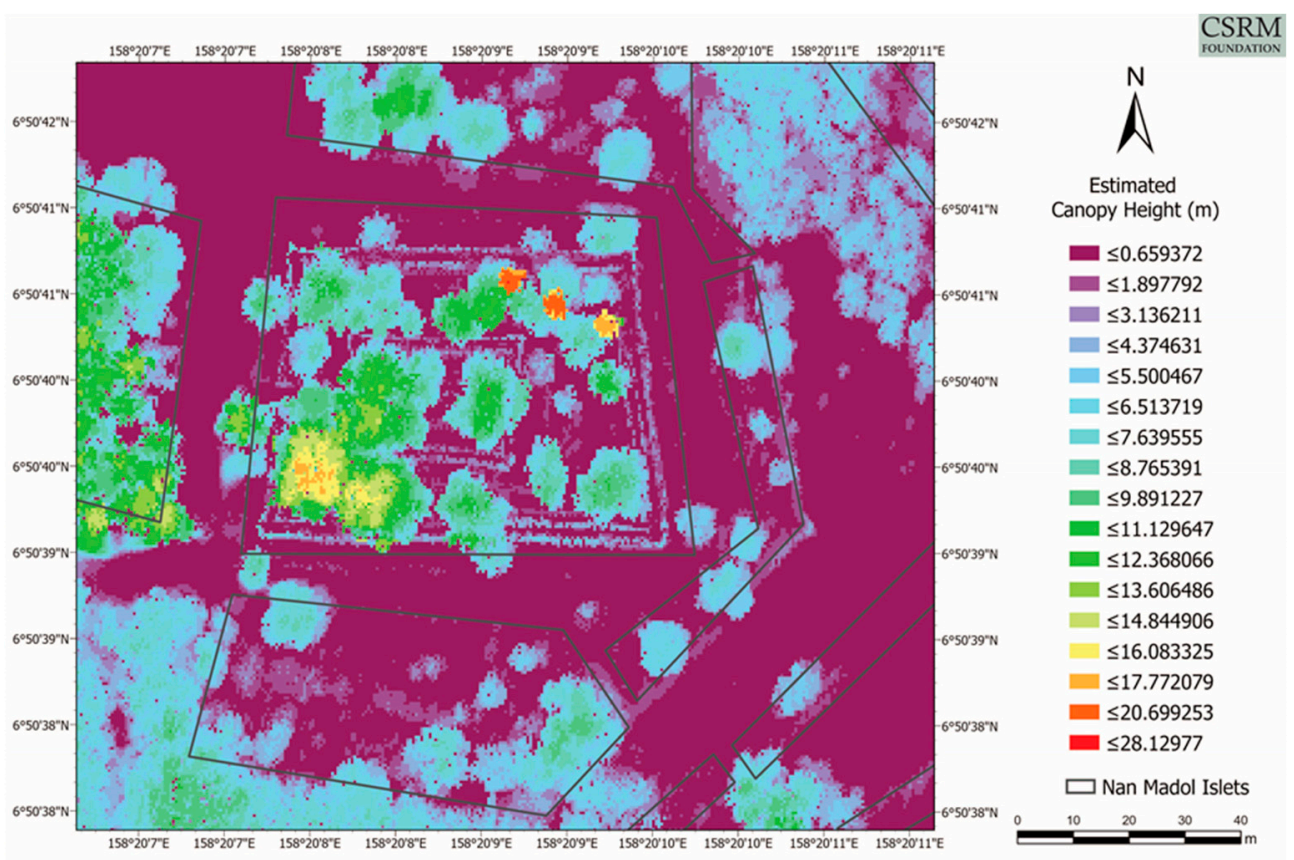

Figure 9. Estimated canopy height and density at Nan Dowas. Note that the model shows three trees with heights between 17.8 and $28.1 \mathrm{~m}$. As height is an important selection criterion for vegetation removal, models like this one will be important tools for vegetation management.

\subsection{Field Verification of LiDAR-Derived Models}

Other data products make the complex system of cultivable areas and water channels across Temwen Island clearly visible (Figures 10 and 11). In addition to simply revealing these features, which are normally hidden from satellite, aerial, and ground-level view by thick vegetation, these products make immediate suggestions about how the cultivation and hydrological systems on Temwen Island functioned and how they might relate to Nan Madol.

Inspection and verification on the ground confirmed the presence of low areas, separated by earthen berms and connected to one another by channels, that allow water to collect in them. The channels that connect these areas allow water to flow from one area to the next. Because they collect water, these low areas are conducive to the growth of certain plants: In several of the areas inspected on the ground, vegetation in the low, wet areas and water channels was distinct, in terms of density and species present, from that on the earthen berms that separate them. This suggests their potential use in the past as wet fields or pondfields for crops such as taro. Water continues to flow, at least after heavy rain (which is common on Pohnpei), through some of these low areas and the channels that connect them. The berms separating these low areas and crossed by the channels may have been cultivated as well, perhaps with cultigens that prefer drier conditions. Such cultivation on raised mounds or platforms has been noted on Pohnpei and elsewhere in Oceania [34,35].

Low areas, water channels, and berms separating them are found on both flat and sloped areas. Systems of low areas, channels, and berms on the sloped areas manifest in the LiDAR-derived products as terrace-like. By clearing vegetation-for example, along a 70-meter transect in western Temwen (Figure 10)—these terrace-like systems, proceeding downslope and transitioning into systems of parallel, alternating low areas and berms on flat ground, were revealed. 


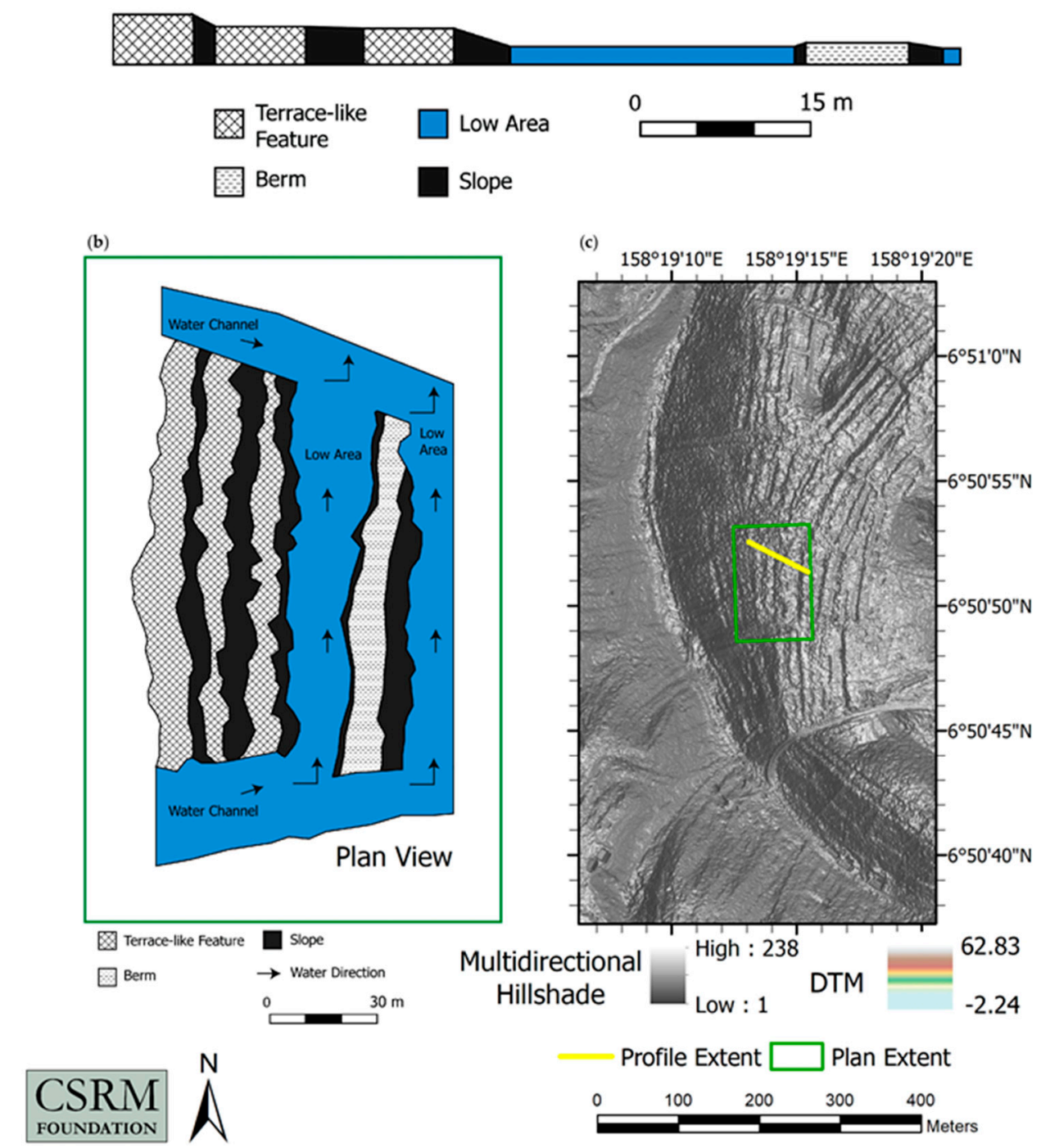

Figure 10. Large-scale landscape modifications in western Temwen Island. In (a), a north-facing profile of the terrace-like features, sloped areas, low areas, and berm that are depicted in the plan view in (b). In (c), the LiDAR-derived multidirectional hillshade, overlaid on the DTM, showing the locations of the profile and plan view. A day after heavy rain on Pohnpei, water was observed flowing through roughly west-east water channels, down the slope of the ridge in western Temwen. As shown in (b), the channels bisect terrace-like features. The channels run into low areas that alternate with berms on flatter ground below the ridge (the alternating pattern continues eastward). The low areas slope gently northward, bringing the water past a series of berms and crossing other west-east channels. If the terrace-like features were originally designed to draw water along their long axes, such water-drawing mechanisms are now defunct.

Fieldwork confirmed that the earthen berms, terrace-like features, and many of the lower areas below and around them are roughly rectangular and elongated in plan. At their highest points, the earthen berms that were observed on the ground are approximately $0.5-1.25 \mathrm{~m}$ high. The observed terrace-like features are approximately $0.25-1.25 \mathrm{~m}$ above the next terrace-like feature or low area. With one possible exception, described below, observed berms and terrace-like features have no retaining walls or other non-earthen support. The margins between them and the lower areas around them, and between one terrace-like feature and the next, are sloped. Aside from these slopes, many of the berms and low areas are level and spacious: One especially large berm in north-central Temwen, 
not surveyed on the ground, can be seen in the LiDAR to cover approximately 2800 square meters, or about 0.7 acres.

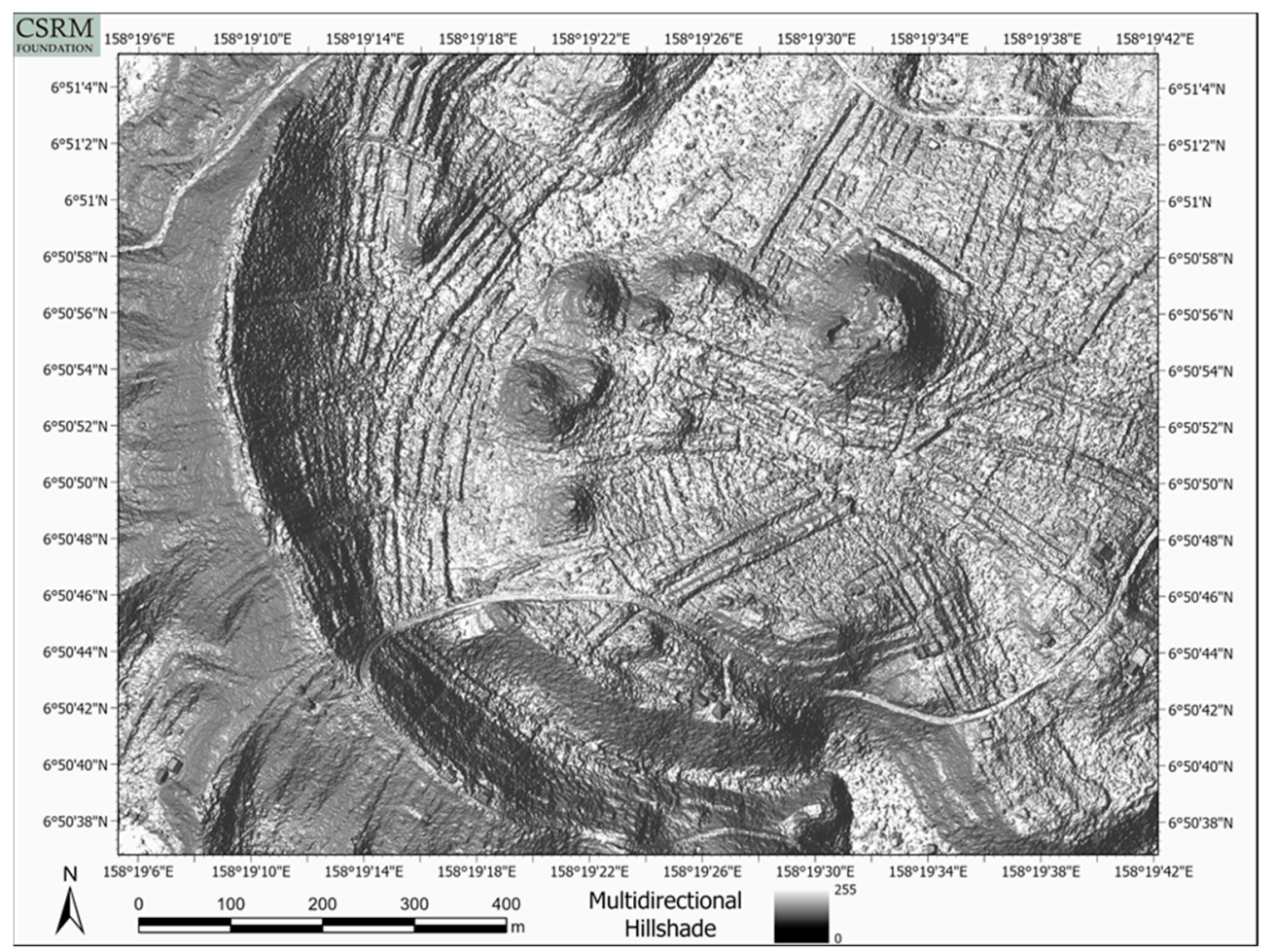

Figure 11. A multidirectional hillshade of the central area of Temwen Island, revealing its complex cultivation system.

LiDAR-derived flow direction (Figure 12) and flow accumulation models (Figure 13) of Temwen Island show how the cultivation features influence the landscape's hydrology. They suggest how the Temwen water management system might have functioned while it was in use, how Temwen's overall topography and hydrology formed a basis for the cultivation system, and how the system interfaced with Nan Madol. Field observations verified that the earthen berms between low areas act as retaining walls for water, altering the natural flow directions that would be expected from the underlying topography. Some channels were observed bringing water from low areas at higher elevations to low areas at lower elevations (Figure 10). Some channels flow past several low areas along their course, suggesting a spatial and water management scheme integrating many areas of cultivation.

In the southwestern part of the island (in Area 4), a wall of basalt boulders, with a similar but smaller wall built on the retained earth behind (roughly east of) it, was found. These were the only potentially constructed stone features found during field verification. As detectable in the LiDAR data, the larger of the two is about $29 \mathrm{~m}$ long. Downslope (roughly west) of these walls were more earthen terraces and channels. These walls could be naturally formed, by volcanic activity, but they appear anthropogenic, and monumental structures are not uncommon on Pohnpei, even outside Nan Madol. Throughout Pohnpei, retaining walls for terraces are typically rock faced (for example, in Awak and Wene; see $[36,37])$. 


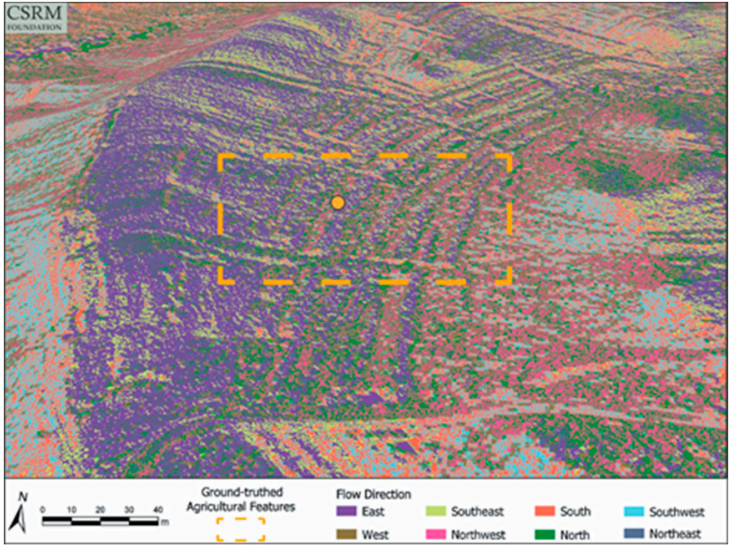

(a)

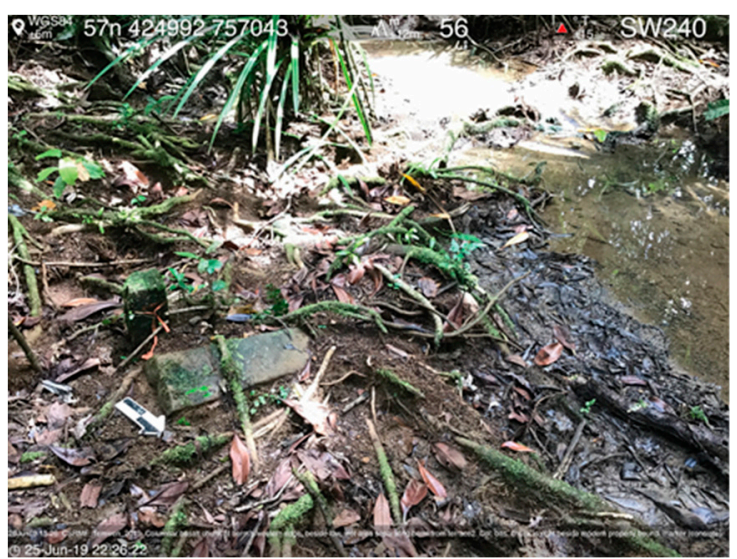

(b)

Figure 12. In (a), a view of the flow direction model created using the DTM; in (b), a photo of the edge of an earthen berm, with water visible in the low area beside it (the photo location is marked in (a) by the orange dot). Note the fragment of columnar basalt (lower left), which does not occur naturally here.

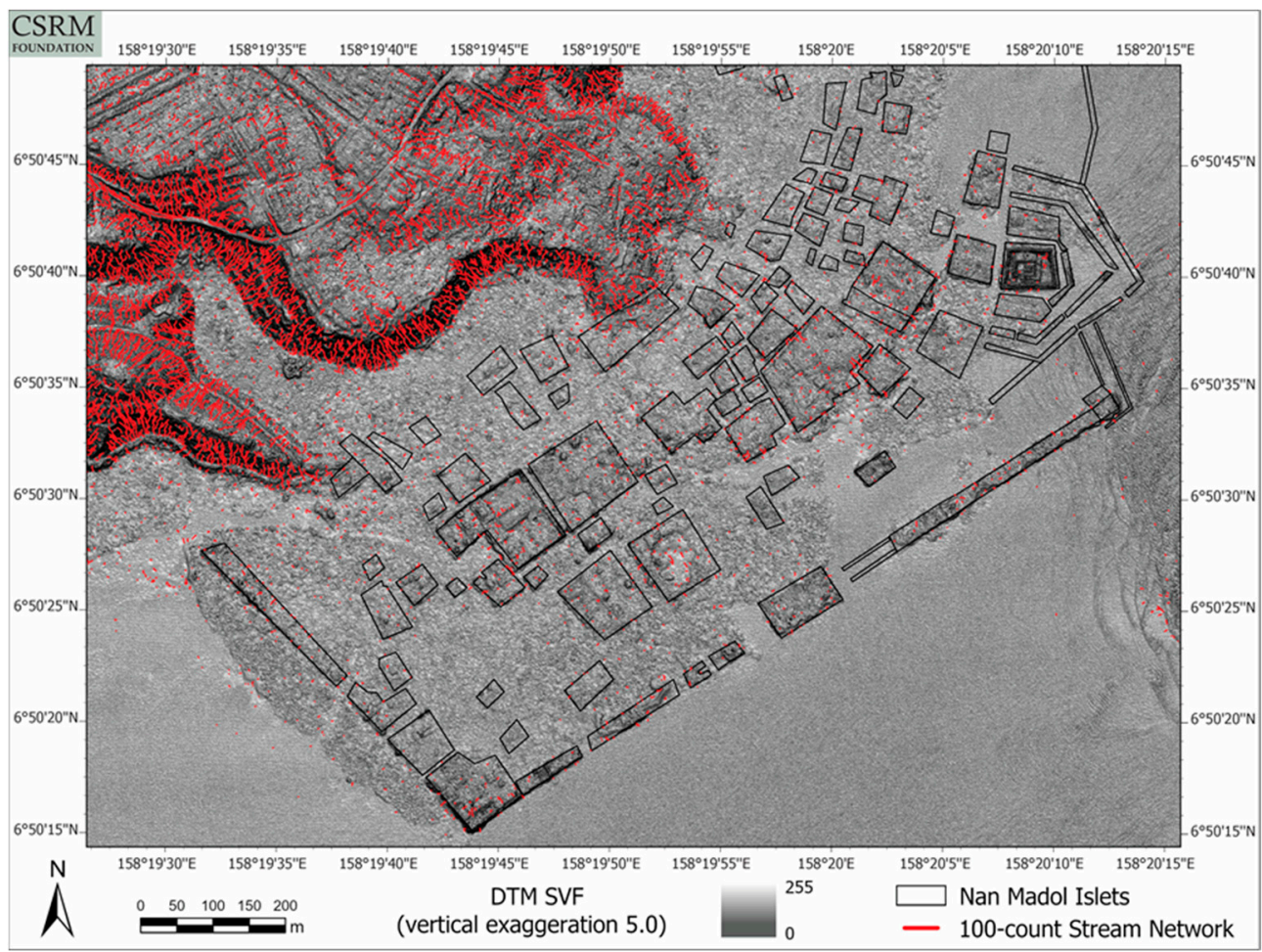

Figure 13. A stream network model (described in Section 2.2). Water flowing along the southern edge of Temwen and along the slopes of the ravine to the northwest of Nan Madol is funneled into the site.

\section{Discussion}

This section discusses the relevance of the LiDAR-derived products to the ongoing conservation planning and activity at Nan Madol. It proceeds to address some of the many implications of the discovery of the Temwen Island cultivation system for understanding and research at Nan Madol, on Pohnpei, and in the region. Current knowledge and ongoing inquiry about the site and its local and regional contexts will be reflected in an interpretive plan, which will constitute part of the larger Sustainable Conservation Plan. 


\subsection{Conservation Objectives}

As mentioned in Section 1.2, salient conservation threats to Nan Madol include disturbance to islets and structures by wind and water, the siltation of the site's canals, and vegetation overgrowth. The LiDAR data set presented here will help design measures to counter each of these.

\subsubsection{Stabilization of Islets and Structures}

Imagery and other data products that were generated from the LiDAR data set will be used to prioritize and guide physical interventions for stabilizing Nan Madol's islets and structures. Models derived from the data set provide convenient and quantifiable means for assessing the physical integrity of archaeological features. The use of the LiDAR's precise elevation measurements to assess and forecast vulnerability to sea level change and acute threats such as storm surges is an example (Figures 7 and 8).

Prior archaeological fieldwork suggests reasons for the differential preservation of Nan Madol islets that is apparent in the LiDAR models. The findings from this fieldwork indicate that the human occupation of areas offshore of Temwen Island predated the artificial islets and monumental structures that comprise Nan Madol [5,6,8,23]. Nan Madol's most intact, and many of its most notable, islets and structures lie along a southwest-northeast axis. These are the islets most visible in Figure 6. Athens, drawing upon his excavations and surveys at the islets $[3,22,23]$, posits the presence of natural islets along that axis that predated Nan Madol's islets. He suggests that the augmentation of these natural islets with basalt and coral rubble inspired the construction of other, later islets both nearer to shore and farther seaward ([5], p. 21).

Later survey and excavation by Ayres of islets closer to the Temwen Island shore show-on the basis of pottery content and architectural form - that those islets are older than ones closer to the outer reef edge. In the inland islets, very little columnar rock is used in construction. Ayres and geologist G. Goles confirmed that most of the construction boulders used in the inland islets were from the adjacent Temwen lava flows (see [38]). Also, at the islet called Dauahpeidak, for example, a concentration of pottery, shell ornaments and food remains was found in a reef sand deposit buried beneath the islet construction. Many of the sherds were water-rolled, indicating either marine reworking of a sand reef islet or materials left as a result of a reef-flat occupation in houses on pilings. This suggested that dwellings on the reef flat predated the development of major artificial islets. This would be consistent with earlier Lapita and post-Lapita residential locations known from Melanesia. Between the idea of marine reworking of a sand reef islet and that of reef-flat occupation in houses on pilings, Ayres favored the latter as a working hypothesis. In any case, he did not think that the use of basalt boulders to construct the artificial islet foundations was necessarily linked to sea level change [6,7]. Columnar basalt was used as facing on some of the earlier islets, but might have been placed later to enhance the islets' prestige.

Athens [23] and others $[6,7,13,21,39,40]$ tell us that Nan Madol's islets differ greatly in construction technique, features, pattern and shape, and the oral accounts associated with them. In Figure 6, the islets along the southwest-northeast axis display the greatest structural integrity and are at higher elevations above MSL than are those to the landward and seaward. These islets have been identified by numerous ethnographers, ethnohistorians, and archaeologists as the most significant with regard to the roles they played in the Saudeleur socio-political system (see e.g., $[16,20,41,42]$ ). That these islets are relatively well preserved is consistent with the construction scenarios offered by Athens and Ayres. Such assessments assist in supporting decisions about prioritizing islets and structures for conservation treatments. These treatments could include vegetation removal and physical stabilization of structures. Erosion has caused deflation of both inland and seaward islets, and most of the landward islets have been damaged by siltation and tidal flooding $[39,40]$. These damaging influences make an exact count of islets difficult; only one new islet has been recorded since the 1970s. 


\subsubsection{Hydrology and Siltation of Nan Madol's Canals}

The development of the landscape of cultivation features on Temwen Island altered the island's hydrology and the flow of water into and through the canals at Nan Madol. As a result, rainfall runoff into Nan Madol may be lower than what would be expected on a natural Temwen Island landscape. This may have been the case even while the cultivation system was being maintained. At present, there can be little doubt that water flow through the network of water channels is blocked because of the degradation of the network, due to causes such as heavy vegetation on Temwen Island, historic landscape modifications, and ground disturbance by pigs.

With physical treatments such as vegetation clearance and targeted maintenance of the water management system, it may be possible to increase the flow of runoff into and through Nan Madol's canals. This would offer a minimally invasive way of clearing silt, which is linked with problematic vegetation overgrowth, from the canals. The LiDAR data set will continue to be used to model the hydrology and vegetation of Temwen Island and Nan Madol to assess the feasibility of testing such treatments.

\subsubsection{Vegetation Management}

LiDAR models show the location and density of mangroves (Figure 6). These models will be used to guide the clearance of mangroves from selected areas. Priority areas include the canals that skirt the most notable of Nan Madol's islets. Ideally, mangroves will not be completely removed from these canals but allowed to remain in place along the canals' edges, much as they often do along the banks of natural rivers. Removing mangroves completely could destabilize the walls of the islets along which the canals flow. Mangroves also provide some protection from tidal cycles and storm surges and serve important ecological roles. Allowing the mangroves to grow unchecked, however, impedes water flow through the canals, encouraging siltation and further overgrowth, as well as making the canals impassable.

Other LiDAR models have been created to highlight trees likely to fall or from which limbs might drop (Figure 9). Falling trees and limbs have damaged structures and the islets themselves at Nan Madol. These models will be used during the initial removal of threatening vegetation.

The LiDAR imagery shows a large area in the ravine on the south side of Temwen Island that has been used in recent decades as a field for growing swamp taro. This large field is now almost completely abandoned; local residents say that many members of the family that once grew swamp taro there have left Pohnpei. The remaining few members now grow taro only in an area adjacent to the house in which they live. Clearing this area of vegetation might assist efforts to further document the Temwen cultivation system as well as to increase water flow into Nan Madol.

\subsection{Implications and Interpretation Objectives}

LiDAR has revealed a massive and complex cultivation system on Temwen Island. It is this advantage of LiDAR, that it can reveal whole archaeological landscapes hidden under heavy vegetation, that has led to its comparison with radiocarbon dating as a groundbreaking technological advance in archaeology. By virtue of its abilities to provide data sets that can reveal an enormous range of archaeologically relevant features and are, geospatially, not merely representative but nearly complete, the importance of LiDAR is difficult to overstate (see $[43,44]$ ). Further LiDAR surveys, not only of other parts of Pohnpei but of other Pacific islands, could contextualize the Temwen system and offer new synoptic perspectives.

In plan, the low, water-collecting areas; water channels; and berms on Temwen are similar to the systems of terraces described by Sand in New Caledonia, which he writes are "considered as the most elaborate of the Western Pacific" ([45], p. 167). Within that system, associated with the Traditional Kanak Cultural Complex from the second millennium CE, he documents terraces, water channels, and pondfield sites. In describing the construction and use of these systems, Sand cites Captain James 
Cook's observation that "not an Inch [sic] of ground is lost" ([46], p. 538). The system has been described as "certainly the most technically complex pondfield irrigation within Melanesia" ([47], p. 80; cited in [45], p. 167). Such complexity is in accord with what is observed in the LiDAR images of Temwen Island. The Temwen system also bears a resemblance to some Polynesian terracing systems, including the Kohala field system on Hawai'i Island [48] and recently described slope terraces on Tutuila in American Samoa [49].

As mentioned in Section 3, retaining walls for terraces on Pohnpei are typically rock faced [37]. That Temwen's cultivation features are almost entirely earthen is therefore unusual. This is perhaps explained in part by the paucity of surface rock on Temwen Island. There is a notable exception about half a kilometer to the east of the abovementioned walls, where a profusion of basalt boulders lies on and near an approximately south-facing slope down to the lagoon. (These boulders could have been rolled down the slope into Nan Madol.) The basalt walls are at the head of a ravine that runs down to the northwestern edge of Nan Madol, the same ravine mentioned in Section 4.1.3. This ravine might have brought fresh water to a point at which it could have been relatively easily collected by the site's inhabitants. The flow of water through the ravine and into the site might also have encouraged water flow through the site itself, potentially clearing sediment from the canals (Figure 13).

The LiDAR models presented here provide the first view of an intensive cultivation system, including water control features, of such scale in the Central and Eastern Caroline Islands. This finding is relevant to ongoing discussions of the development of social complexity throughout the Pacific. Previous localized archaeological surveys and excavations on Pohnpei documented terraces and alignments that were interpreted as agricultural features [34,50-54], some with water control mechanisms (see [34], p. 151). Yet a large, complex system with integrated water channels had not been posited.

Without the view provided by LiDAR, archaeologists who have done research on Pohnpei, and in particular at Nan Madol, have generally emphasized the importance of breadfruit (see e.g., [55], p. 85), yams, and reef fish, with taro contributing little to the Pohnpeian diet. Though the role of bananas is acknowledged, it is understudied, likely because of their lack of prestige in the traditional food system or their limited archaeological visibility [56]. None of these foods can be effectively preserved once harvested, with the exception of breadfruit, and less commonly banana, which can be fermented [34,55-57]. This makes year-round cultivation and harvest of crops necessary. Food security has long been seen as having shaped Pohnpeian culture (and Micronesian culture more broadly) in several defining ways, including by encouraging the improvement of inter-island connections $[53,58]$ and social systems that emphasize the production of large amounts of food for feasting $[18,54,59]$. But food production on a scale made possible by the cultivation system described here has not been previously suggested.

The Temwen cultivation system can be considered landesque capital in the sense used by Håkansson and Widgren: A choice of agricultural techniques that serve important economic, social, and ritual purposes [60]. The term was originally used by Sen to refer simply to capital goods that replace land (as opposed to laboresque capital, which replaces labor) [61]. In this strictly economic sense, too, the Temwen system fits the concept: Spriggs maintains that irrigated systems for growing taro can generate yields at least four times higher than what is possible with swidden agriculture ([62], cited in [63]).

The concept of landesque capital has been used by geographers and anthropologists to explore food storage as it relates to exchange in the service of food security and the prestige economy. Under certain conditions, for example, concentrations of landesque capital could have generated tradable surpluses of foods such as taro $[64,65]$. Such tradable surpluses would have constituted wealth, or, as Bayliss-Smith and Hviding put it, "social and nutritional value to be saved, accumulated, and later mobilized" ([64], p. 425).

Without extensive archaeological fieldwork or the application of technologies like LiDAR, it can be easy to overlook the physical evidence even of large investments in landesque capital. In 1568, the first Europeans to arrive at the island of Guadalcanal, in the Solomon Islands, saw a planned 
agricultural landscape. In 1610, a Captain de Queirós, on his way to Vanuatu, wrote to the King of Spain that he had observed gardens "artificially severed (divided) into beds, bordered, and paled (fenced)" ([66], p. 221; quoted in [63], p. 75). Yet when Europeans next recorded what they saw on Guadalcanal in the nineteenth century, there was little trace of terracing or irrigation [63]. It was only in 2000 that an archaeologist, David Roe, discovered remnants of stone walls, terraces and irrigated fields [67]. On Vanuatu, Bayliss-Smith and Hviding have examined historical documentation by de Queirós that engineered landscapes for taro production existed in the Tavai, Apuna, and Raovi valleys and their inland catchments [63].

The existence of the Temwen system supports the hypothesis of Ayres et al. that Temwen Island served as an agricultural area to support Nan Madol, and that evidence of agricultural intensification would be found there ([40], p. 9). To investigate this, Ayres and colleagues conducted fieldwork in 2011 that documented several features, such as stone walls that were suspected to have been an element of terraces. They report finding 13 boulder alignments thought to be related to terracing, seven stone platforms or enclosures, and four stone walls, as well as other agricultural features, such as yam enclosures and breadfruit fermentation pits ([40], p. 42; [52], p. 60).

These findings were preceded by others that are consistent with the interpretation of the Temwen Island features as relating to cultivation and possibly coeval with Nan Madol's fluorescence. Ayres and Haun found water control features, terraces, enclosures, pits, and walls in Pohnpei's Awak Valley [36] (see also [37]). Many of these features are agricultural. Among them are terraces along stream courses that the researchers suggested might be wet terraces for taro cultivation.

\section{Conclusions}

The LiDAR survey discussed here was done to advance the goals of the U.S. Department of State-funded Sustainable Conservation Plan for Nan Madol. Chief among these goals is to ameliorate threats to the Nan Madol World Heritage Site so that the site can be removed from the List of World Heritage in Danger. The discovery of an extensive and sophisticated cultivation system influences decisions that must be made about conservation treatments and a site management plan. This management plan will provide for site monitoring, cyclical maintenance, interpretation, facilities, visitor services, and site and visitor protection.

It is likely that the Temwen system revealed by LiDAR is contemporaneous with the islets and structures of the Nan Madol World Heritage Site. The system is comparable to the islets and structures of Nan Madol in terms of the complexity and magnitude of the effort that would have been required to build and maintain it. The investment of labor, for example, and the level of social organization necessary to construct and maintain the Temwen system would appear to be similar to what would have been required to construct and maintain Nan Madol. If the Temwen system is a creation of the Saudeleur Dynasty, it emphasizes the high level of social organization associated with the dynasty; regardless, it suggests many avenues for future research.

The LiDAR models presented here comprise the most convincing evidence thus far for a formal, complex cultivation system incorporating an intensive network of growing areas and water management features in the Central and Eastern Carolines. This is the region of Micronesia thought to have been initially settled by Lapita-descendant communities. Further investigations on Temwen Island, and comparative studies, will be needed to determine how this development might inform the chronology and pattern of human interaction among the islands in the region.

Dateable samples from the field system might prove informative not only regarding how the development of the field system and that of Nan Madol's islets and structures compare chronologically, but also where a model for the field system might have originated. Athens states that the pottery found at Nan Madol is best described as belonging to the Late Lapita Plain Ware pottery tradition, which he considered to be unlike pottery found elsewhere in Micronesia, based on shape and decorative technique: A simple globular form for pots and bowls, "with perhaps some rim notching or punctuation" ([5], p. 29). He sees this form and decoration persisting over the centuries, despite changes in temper 
(p. 26). Athens further states that Late Lapita Plain Ware is found only in the southeast Solomon and New Hebrides islands (the latter now Vanuatu; see also [24]). Lebot's observation that the kava sub-species found on Pohnpei is most similar to that on Vanuatu and the Bismarcks constitutes another link between Pohnpei and that region [68].

Comparative studies in the future could also address the spread of stone architecture through the Pacific. As Carson notes ([69], p. 2), "the stone city of Nan Madol in Pohnpei has long been regarded as the 'Venice of the Pacific,' with its canals leading through a labyrinthine network of long-abandoned stonework architecture, but rarely is this discussed in relation to the other monumental stonework traditions that developed throughout Micronesia and the Pacific all about the same time." McCoy and colleagues have presented evidence that Nan Madol's stone architecture is among the Pacific's oldest ([2], p. 295). It remains to be determined how Nan Madol might be related to the spread of Pacific stone architecture, and how the discovered landscape of cultivation features might further this line of inquiry.

The cultivation system reported on here could be an important reference for future research on the development of such systems in the Pacific. Though oral histories indicate that Nan Madol received food as tribute from across Pohnpei, the resident population could not have been adequately fed by food grown or obtained on site. The site itself could not have produced enough food for food-focused ritual and feasting. To the degree that it provided food, and food security, to Nan Madol, the Temwen cultivation system carries enormous implications for the site.

The Temwen system would appear from our inspection on the ground to have formed wet fields suitable for growing taro. Soil testing, including analyses of pollen samples, phytoliths, and plant macroremains, is likely needed to confirm this. Devoting a substantial proportion of the Temwen system to taro would have resulted in an enormous and relatively secure store of food. Such a supply of taro could have been tapped not only for redistribution or trade [64], but also for feasting that enhanced the prestige of the rulers. If a suitable method can be devised to preserve or store it, food constitutes a form of wealth: Food is essential and, contingent on the preservation or storage method, it can be reapplied or reallocated. Under certain circumstances, it can be traded for, among other desirable materials and objects, prestige goods (some of which are themselves foods).

A deeper understanding of the Temwen cultivation system and its relation to Nan Madol requires research on how the system functioned: How the features were built or maintained, and how they harmonized with cultivation methods and environmental dynamics. This calls for studies such as sampling and analyzing the construction of the features, investigating the chronology of the Temwen system's development and how it relates to Nan Madol's growth, and comparing Temwen with early field systems in other parts of the Pacific. Comparison or analogy with traditional Pohnpeian cultivation methods, following Carson's method in Samoa [70], could also be informative.

Detailed knowledge of the Temwen system will allow future researchers to draw conclusions about Nan Madol's food security and wealth; how these advantages contributed to the site's development, construction, and maintenance; and the economic and political strategies of Nan Madol's rulers. With its socio-political, ritual, and economic importance, Nan Madol may have served as a symbol of affluence and stability to other islands and atolls in the region. As such, in times of need, such as those triggered by typhoons or droughts, Nan Madol may have been looked to by regional neighbors or clan members from elsewhere in Micronesia for aid or trade. This idea is supported by Petersen's argument that the presence of members of clans on numerous islands and atolls across Micronesia created a network of support and trade for voyagers and clan members in need [58]. If such a model holds, then the food security and wealth that supported Nan Madol would have made it an important node at the center of regional social and economic networks. 
Author Contributions: Conceptualization, D.C.C. and J.A.C.; data curation, J.A.C., I.A.D. and D.A.W.; formal analysis, J.A.C., I.A.D. and D.A.W.; funding acquisition, D.C.C.; investigation, D.C.C., J.A.C. and I.A.D.; methodology, D.C.C., J.A.C., I.A.D. and D.A.W.; project administration, D.C.C., J.A.C. and I.A.D.; resources, D.C.C., J.A.C., I.A.D. and M.J.H.; software, D.A.W.; supervision, D.C.C., J.A.C., I.A.D., W.S.A., D.A.W. and M.J.H.; validation, D.C.C. and J.A.C.; visualization, I.A.D. and D.A.W.; writing-original draft, D.C.C.; writing-review \& editing, D.C.C., J.A.C., I.A.D. and W.S.A., M.J.L., K.A.S., D.A.W. and M.J.H.

Funding: This research was funded by the U.S. Department of State via an Ambassadors Fund for Cultural Preservation large grant, award number SLMAQM18GR2224.

Acknowledgments: The airborne LiDAR investigation central to the findings presented here was made possible by the U.S. Department of State Ambassadors Fund for Cultural Preservation program. We are deeply indebted to those at the Department of State who, through this program, made our large grant possible and have assisted and encouraged the project in a great many ways. We thank Robert Riley, Heather Coble, Abigail Kim, Martin Perschler, and Adam Shapiro. Our work would not have been possible without the advice and support of the Nahnmwarki of Madolenihmw, Augustus Kohler, John Ehsa, and Mordain David. We also thank Kukulyn Gallen, Canita Rilometo, Joseph Daisy, Sharon Sawdey, Thomas Beckmann, Nicholson Solomon, Ricky Lebehn, and Rex Prosia. Many Pohnpei State Historic Preservation Office personnel assisted us in the field, including Randy Joswa, Semes Silbanus, Martin Sarapio, Peterson Silbanus, Joe Barnabas, Elson Lipai, and Jason Barnabas. We are also very grateful for the guidance of Romeo Walter, of Pohnpei State Resources and Development. This work would have been impossible without their help. In our field investigations, we enjoyed and benefited from the participation of Denise Oen. Along with filmmaker Daniel Lin, Dr. Oen is overseeing the efforts of a group of COM student filmmakers who are making a documentary about Nan Madol that includes material on our project. We are grateful for the student filmmakers' knowledge and enthusiasm, which helped and energized us in the field. Delma Henry and Mark Lawrence provided us with the names of the people who own the areas we needed to inspect for the ground verification and validation that support this paper. These landowners are too numerous to name, but this work could not have proceeded without their graciousness and help. At the U.S. National Oceanic and Atmospheric Administration (NOAA) office in Kolonia, Eden Skilling provided us with information about Pohnpei's tides. We thank the following for participating in meetings, joining us in field excursions, or providing suggestions, emails, or notes: John Peterson, Ashley Meredith, Takuya Nagaoka, Marjorie Falanruw, Curt Storlazzi, Tom Garrison, and Damian Evans. We thank Tom Pattinson and George Fraser, of Aerial Surveying, Inc., for their patience and tenacity in carrying out the LiDAR survey that made this work possible. We are grateful to Patrick Kim and Rob Wanner for their help in revising the figures.

Conflicts of Interest: The authors declare no conflicts of interest.

\section{References}

1. Primo, A. Colocasia taro on Pohnpei Island. In Proceedings of the Sustainable Taro Culture for the Pacific Conference, Honolulu, HI, USA, 24-25 September 1992.

2. McCoy, M.D.; Alderson, H.A.; Hemi, R.; Cheng, H.; Edwards, R.L. Earliest direct evidence of monument building at the archaeological site of Nan Madol (Pohnpei, Micronesia) identified using $230 \mathrm{Th} / \mathrm{U}$ coral dating and geochemical sourcing of megalithic architectural stone. Quat. Res. 2016, 86, 295-303. [CrossRef]

3. Athens, J.S. Archaeological Investigations at Nan Madol: Islet Maps and Surface Artifacts; Pacific Studies Institute: Agana, GU, USA, 1980.

4. Athens, J.S. Nan Madol: Archaeology of a Pohnpeian Chiefdom Center; Report Submitted to the Office of Historic Preservation; Office of Historic Preservation: Saipan, OK, USA, 1985.

5. Athens, J.S. Nan Madol pottery, Pohnpei. Micronesica 1990, 2, 17-32.

6. Ayres, W.S. The Archaeology of Nan Madol, Ponape, Micronesia (Eastern Caroline Islands); The National Geographic Society: Washington, DC, USA, 1985.

7. Ayres, W.S. Nan Madol Archaeological Fieldwork: Final Report; Historic Preservation Office: Pohnpei, Micronesia, 1993.

8. Ayres, W.S. Pohnpei's position in eastern Micronesian prehistory. Micronesica 1990, 2, 187-212.

9. Ayres, W.S.; Seikel, K. Burial Practises in the Archaeological Record on Pohnpei, Eastern Micronesia. In Monuments and People in the Pacific; Department of Archaeology and Ancient History, Uppsala University: Uppsala, Sweden, 2014; pp. 129-166.

10. Bath, J.E.; Athens, J.S. Prehistoric social complexity on Pohnpei: The Saudeleur to Nahnmwarki transformation. Micrones. Suppl. 1990, 2, 275-290.

11. Mauricio, R. Ideological Bases for Power and Leadership on Pohnpei, Micronesia: Perspectives from Archaeology and Oral Tradition. Ph.D. Thesis, University of Oregon, Eugene, OR, USA, 1993. 
12. McCoy, M.D.; Alderson, H.A.; Thompson, A. A new archaeological field survey of the site of Nan Madol, Pohnpei. Rapa Nui J. 2015, 29, 5-22. [CrossRef]

13. Saxe, A.A.; Allenson, R.; Loughridge, S.R. The Nan Madol Area of Ponape: Researches into Bounding and Stabilizing an Ancient Administrative Center; Historic Preservation Office, Office of the High Commissioner: Saipan, Mariana Islands, 1980.

14. Seikel, K. Mortuary contexts and social structure at Nan Madol, Pohnpei. J. Isl. Coast. Archaeol. 2011, 6, 442-460. [CrossRef]

15. Seikel, K. Prehistoric Socio-Political Structure on Pohnpei: Perspectives from Mortuary Contexts. Ph.D. Thesis, The Australian National University, Canberra, Australia, 2016.

16. Bernart, L. The Book of Luelen; University Press of Hawaii: Honolulu, HI, USA, 1977.

17. Hanlon, D.L. Upon a Stone Altar: A History of the Island of Pohnpei to 1890; University of Hawaii Press: Honolulu, HI, USA, 1988; Volume 5.

18. Bascom, W.R. Ponape: A Pacific Economy in Transition; University of California Press: Berkeley, CA, USA, 1965; Volume 22.

19. Riesenberg, S.H. Native Polity of Ponape. Smithson. Contrib. Anthropol. 1968. [CrossRef]

20. Hambruch, P. Results of the South Seas Expedition: 1908-1910. Sect. II, part 3, vol. 7, translation by Murphy, E.A., and Runeborg, R.E.; on file at the University of Hawaii. 1936. Available online: https: //guides.library.manoa.hawaii.edu/Sudsee-Expedition/bibliography (accessed on 7 July 2019).

21. Kubary, J.S. Die Ruinen von Nanmatal auf der Insel Ponope (Ascension); Geographische Gesellschaft: Hamburg, Germany, 1873.

22. Athens, J.S. Pottery from Nan Madol, Ponape, Eastern Caroline Islands. J. Polyn. Soc. 1980, 89, 95-99.

23. Athens, J.S. Surface artefact distributions at the Nan Madol Site: A preliminary assessment of spatial patterning. N. Z. J. Archaeol. 1984, 6, 129-153.

24. Bryson, R.U. Ceramics and Spatial Archaeology at Nan Madol, Pohnpei. Ph.D. Thesis, University of Oregon, Eugene, OR, USA, 1989.

25. Riesenberg, S.H. United States Government Memorandum (to Dr. Leonard Carmichael): Report on Detail to Fieldwork at Ponape, January 20 to March 14, 1963; Smithsonian Institution National Anthropological Archives: Suitland, MD, USA, 1963.

26. Athens, J.S. The rise of the Saudeleur: Dating the Nan Madol chiefdom, Pohnpei. In Vastly Ingenious-The Archaeology of Pacific Material Culture in Honour of Janet M. Davidson; Otago University Press: Dunedin, New Zealand, 2007; pp. 191-208.

27. Ayres, W.S. Island archaeology and issues of political centralization: Micronesian evidence. Bar Int. Ser. 2002, 1095, 57-67.

28. White, D.A. LIDAR, Point Clouds, and Their Archaeological Applications. In Mapping Archaeological Landscapes from Space; Comer, D.C., Harrower, M.J., Eds.; Springer: New York, NY, USA, 2013; pp. 175-186.

29. Zakšek, K.; Oštir, K.; Kokalj, Ž. Sky-view factor as a relief visualization technique. Remote Sens. 2011, 3, 398-415. [CrossRef]

30. Relief Visualization Toolbox (RVT). Available online: https://iaps.zrc-sazu.si/en/rvt\#v (accessed on 16 August 2019).

31. UNESCO World Heritage Committee. Report of the Decisions Adopted during the 40th Session of the World Heritage Committee; UNESCO: Paris, France, 2016.

32. ICOMOS. Evaluations of Nominations of Cultural and Mixed Properties to the World Heritage List: ICOMOS Report for the World Heritage Committee 40th Ordinary Session, Istanbul, 10-20 July 2016; Secrétariat ICOMOS International: Charenton-le-Pont, France, 2016; pp. 103-112.

33. Sand, C.; Lebehn, J.; Silbanuz, S.; Walter, P.S.; Barnabas, J.; Hebel, M. Looking for the Basis of Nan Madol's Platforms: Coring and Test-Pit Excavations in Some Channels and Structures of Pohnpei's World Heritage Property (Federated States of Micronesia) (23rd January-3rd February 2018); UNESCO: Paris, France; Institut d'archéologie de la Nouvelle-Calédonie et du Pacifique: Nouméa, New Caledonia, 2018.

34. Haun, A.E. Prehistoric Subsistence, Population, and Sociopolitical Evolution on Ponape, Micronesia. Ph.D. Thesis, University of Oregon, Eugene, OR, USA, 1984.

35. Spriggs, M. Taro Cropping Systems in the Southeast Asian-Pacific Region: Archaeological Evidence. Archaeol. Ocean. 1982, 17, 7-15. [CrossRef] 
36. Ayres, W.S.; Haun, A.E. Ponape Archaeological Survey: 1977 Research; Micronesian Archaeological Reports No.1; Historic Preservation Office: Saipan, OK, USA, 1980.

37. Ayres, W.S.; Haun, A.E.; Severance, C. Subsistence and Settlement on Ponape, Micronesia; Micronesian Archaeological Survey Reports No. 4; Historic Preservation Office: Saipan, OK, USA, 1981.

38. Ayres, W.S.; Scheller, C.J. Status architecture and stone resources on Pohnpei, Micronesia: Experiments in stone transport. In Pacific Archaeology: Essays in Honor of Richard Shutler, Jr.; Sand, C., Burley, D., Eds.; Centre National de la Recherche Scientifique: Noumea, New Caledonia, 2003; pp. 109-121.

39. Ayres, W.S.; Seikel, K.; Levin, M.J. Archaeological Remains at Angeir-Karian, Nan Madol, Pohnpei, Federated States of Micronesia, with Supplemental Studies at Sokehs and Temwen, Pohnpei; Pohnpei State Historic Preservation Program: Pohnpei, Micronesia, 2009.

40. Ayres, W.S.; Seikel, K.; Levin, M.J. Archaeological Survey, Architectural Studies and Agricultural Analysis. Nan Madol and Temwen, Pohnpei; Historic Preservation Office: Pohnpei, Micronesia, 2015.

41. Sand, C. Nan Madol World Heritage Property-Federated States of Micronesia: Draft Conservation Plan-2018; International Assistance Request number 2882 ("Initial non-invasive clearing of vegetation overgrowth at Nan Madol"); UNESCO: Paris, France, 2018.

42. Riesenberg, S. The Native Polity of Pohnpei; Smithsonian Institution Press: Washington, DC, USA, 1968.

43. Chase, A.F.; Chase, D.Z.; Fisher, C.T.; Leisz, S.J.; Weishampel, J.F. Geospatial revolution and remote sensing LiDAR in Mesoamerican archaeology. Proc. Natl. Acad. Sci. USA 2012, 109, 12916-12921. [CrossRef] [PubMed]

44. Chase, A.F.; Chase, D.Z.; Weishampel, J.F. The Use of LiDAR at the Maya Site of Caracol, Belize. In Mapping Archaeological Landscapes from Space; Comer, D.C., Harrower, M.J., Eds.; Springer: New York, NY, USA, 2013; pp. 187-197.

45. Sand, C. 'Certainly the Most Technically Complex Pondfield Irrigation Within Melanesia': Wet Taro Field Systems of New Caledonia. Senri Ethnol. Stud. 2012, 78, 167-188.

46. Beaglehole, C. The Journals of Captain James Cook on His Voyages of Discovery. The Voyage of the Resolution and Adventure, 1772-1775 (Vol. II); Hakluyt Society at the University Press: Cambridge, UK, 1961; p. 538.

47. Barrau, J. L'Agriculture Vivrière Autochtone de la Nouvelle-Calédonie; Commission du Pacifique Sud: Nouméa, New Caledonia, 1956.

48. Ladefoged, T.N.; McCoy, M.D.; Asner, G.P.; Kirch, P.V.; Puleston, C.O.; Chadwick, O.A.; Vitousek, P.M. Agricultural potential and actualized development in Hawai'i: An airborne LiDAR survey of the leeward Kohala field system (Hawai'i Island). J. Archaeol. Sci. 2011, 38, 3605-3619. [CrossRef]

49. Cochrane, E.; Mills, J. LiDAR imagery confirms extensive interior land-use on Tutuila, American Sāmoa. J. Pac. Archaeol. 2018, 9, 70-78.

50. Ayres, W.S.; Haun, A.E. Archaeological Perspectives on Food Production in Eastern Micronesia; British Archaeological Reports: Oxford, UK, 1985; Volume 232.

51. Ayres, W.S.; Haun, A.E. Prehistoric Food Production in Micronesia. In Pacific Production Systems: Approaches to Economic Prehistory. Papers from a Symposium at the XVth Pacific Science Congress, New Zealand; The Australian National University: Canberra, Australian, 1990.

52. Levin, M.J. Food Production, Environment, and Culture in the Tropical Pacific: Evidence for Prehistoric and Historic Plant Cultivation in Pohnpei, Federated States of Micronesia. Ph.D. Thesis, University of Oregon, Eugene, OR, USA, September 2015.

53. Petersen, G. Micronesia's breadfruit revolution and the evolution of a culture area. Archaeol. Ocean. 2006, 41, 82-92. [CrossRef]

54. Balick, M.J. (Ed.) Ethnobotany of Pohnpei: Plants, People, and Island Culture; University of Hawaii Press: Honolulu, HI, USA, 2009.

55. Hunter-Anderson, R. A review of traditional Micronesian high island horticulture in Belau, Yap, Chuuk, Pohnpei, and Kosrae. Micronesica 1991, 24, 1-56.

56. Levin, M.J. Breadfruit fermentation in Pohnpei, Micronesia: Site formation, archaeological visibility, and interpretive strategies. J. Isl. Coast. Archaeol. 2018, 13, 109-131. [CrossRef]

57. Ragone, D. Breadfruit storage and preparation in the Pacific Islands. In Vegeculture in Eastern Asia and Oceania, JCAS Symposium Series 16; Yoshida, S., Matthews, P.J., Eds.; The Japan Center for Area Studies, National Museum of Ethnology: Osaka, Japan, 2002. 
58. Petersen, G. Traditional Micronesian Societies: Adaptation, Integration, and Political Organization; University of Hawaii Press: Honolulu, HI, USA, 2009.

59. Bascom, W.R. Ponapean prestige economy. Southwest. J. Anthropol. 1948, 4, 211-221. [CrossRef]

60. Håkansson, N.T.; Widgren, M. (Eds.) Landesque Capital: The Historical Ecology of Enduring Landscape Modifications; Left Coast Press: Walnut Creek, CA, USA, 2014.

61. Sen, A.K. The Choice of Agricultural Techniques in Underdeveloped Countries. Econ. Dev. Cult. Chang. 1959, 7, 279-285. [CrossRef]

62. Spriggs, M. The Lapita cultural complex: Origins, distribution, contemporaries and successors. J. Pac. Hist. 1984, 19, 202-223. [CrossRef]

63. Bayliss-Smith, T.; Hviding, E. Taro Terraces, Chiefdoms and Malaria: Explaining Landesque Capital Formation in Solomon Islands. In Landesque Capital: The Historical Ecology of Enduring Landscape Modifications; Håkansson, N.T., Widgren, M., Eds.; Left Coast Press: Walnut Creek, CA, USA, 2014; pp. 75-97.

64. Bayliss-Smith, T.; Hviding, E. Landesque capital as an alternative to food storage in Melanesia: Irrigated taro terraces in New Georgia, Solomon Islands. Environ. Archaeol. 2015, 20, 425-436. [CrossRef]

65. Bayliss-Smith, T.; Hviding, E. Irrigated taro, malaria and the expansion of chiefdoms: Ruta in New Georgia, Solomon Islands. Senri Ethnol. Stud. 2012, 78, 219-254.

66. Purchas, S. Hakluytus Posthumus or Purchas His Pilgrimes in Twenty Volumes; James MacLehose \& Sons: Glasgow, UK, 1906; Volume 17.

67. Roe, D. Maritime, coastal and inland societies in Island Melanesia; The bush-saltwater divide in Solomon Islands and Vanuatu. Mod. Quat. Res. Southeast Asia 2000, 16, 197-222.

68. Lebot, V.; Merlin, M.; Lindstrom, L. Kava: The Pacific Drug; Yale University Press: New Haven, CT, USA, 1992.

69. Carson, M. Archaeology of Pacific Oceania: Inhabiting a Sea of Islands; Routledge: New York, NY, USA, 2018.

70. Carson, M. Samoan Cultivation Practices in Archaeological Perspective. People Cult. Ocean. 2006, 22, 1-29.

(C) 2019 by the authors. Licensee MDPI, Basel, Switzerland. This article is an open access article distributed under the terms and conditions of the Creative Commons Attribution (CC BY) license (http://creativecommons.org/licenses/by/4.0/). 